\begin{tabular}{|c|c|}
\hline $\begin{array}{l}\text { 2. To: (Receiving Organization) } \\
\text { Engineering Support }\end{array}$ & $\begin{array}{l}\text { 3. From: (Originating Organization) } \\
\text { Engineering Support }\end{array}$ \\
\hline $\begin{array}{l}\text { 5. Proj./Prog./Dept./Oiv.: } \\
\text { Spent Nuclear Fuel Project }\end{array}$ & $\begin{array}{l}\text { 6. Design Authority/ Design Agent/Cog } \\
\text { Engr.: } \\
\text { D. R. Precechtel }\end{array}$ \\
\hline
\end{tabular}

8. Originator Remarks:

For release.

3. From: (Originating Organization) 4. Related EDT No.:

Engineering Support

$N / A$

7. Purchase Order No.:

$N / A$

9. Equip./Component No.:

$N / A$

10. System/8ldg./Facility:

$105 \mathrm{~K}$ Basins

11. Receiver Remarks: 11A. Design Baseline Document? [] Yes [X] No

12. Major Assm. Dwg. No.:
NA

13. Permit/Permit Application No.: N/A

14. Required Response Date: N/A

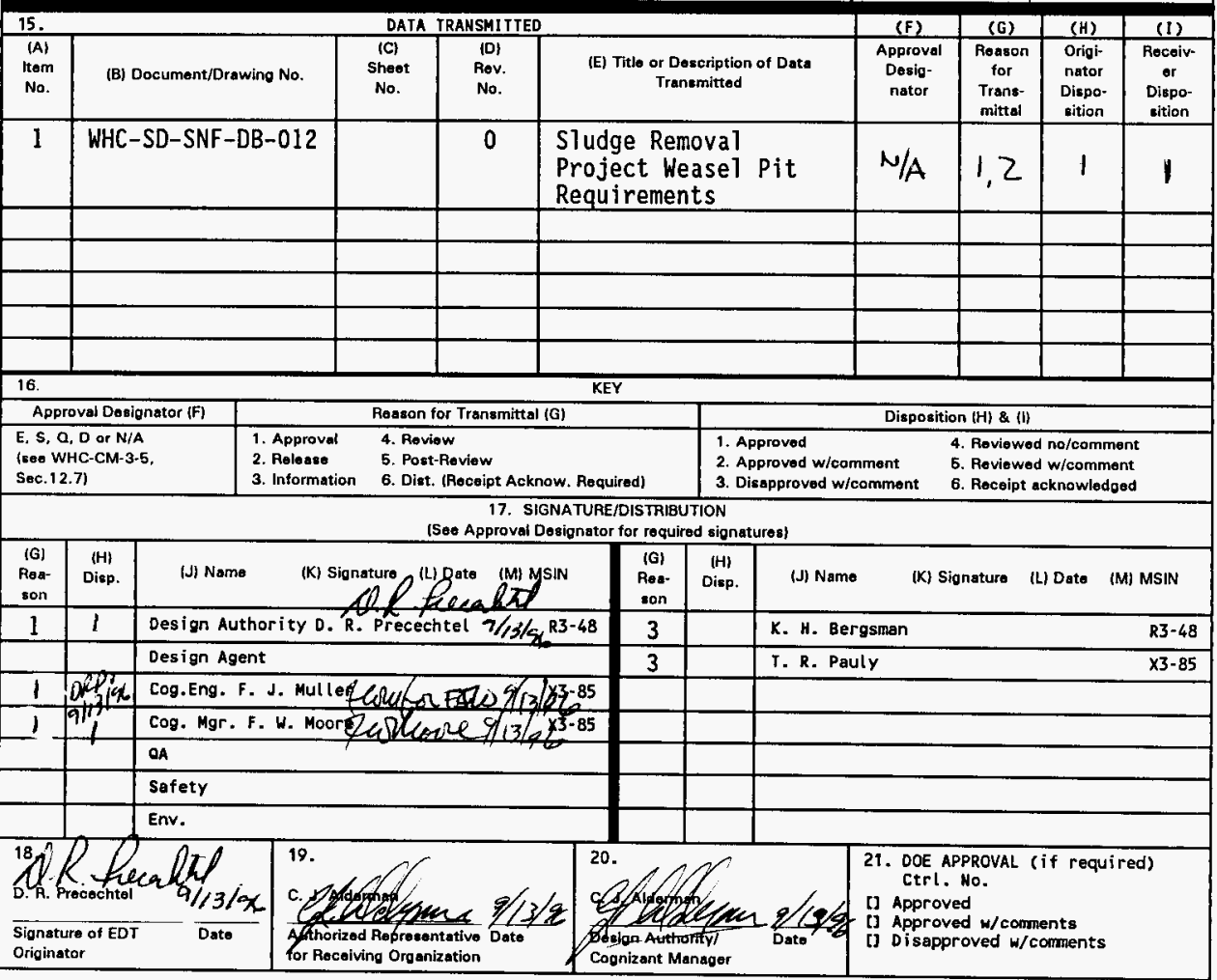




\title{
Sludge Removal Project Weasel Pit Requirements
}

\author{
D. R. Precechtel
}

Westinghouse Hanford Company, Richland, WA 99352

U.S. Department of Energy Contract DE-ACO6-87RL10930
EDT/ECN: 616144
Org Code: 2C500
UC: 600
B\&R Code: EW3135040
Charge Code: LD098
Total Pages: $8986 \mathrm{KmB} 9 / 16 / 96$

Key Words: K Basins, Spent Nuclear Fuel, Sludge, Wease1 Pit, Management Requirements, Sludge Management Requirements

Abstract: This document defines some technical requirements based on design concerns related to storage of $K$ East Basin Sludge in the Wease 1 Pit.

TRADEMARK D1SCLAIMER. Reference herein to any specific commercial product, process, or service by trade name, trademark, manufacturer, or otherwise, does not necessarily constitute or imply its endorsement, recommendation, or favoring by the United States Government or any agency thereof or its contractors or subcontractors.

Printed in the United States of America. To obtain copies of this document, contact: WHC/BCS Document Control Services, P.O. Box 1970, Mailstop H6-08, Richland WA 99352, Phone (509) 372-2420; Fax (509) $376-4989$.
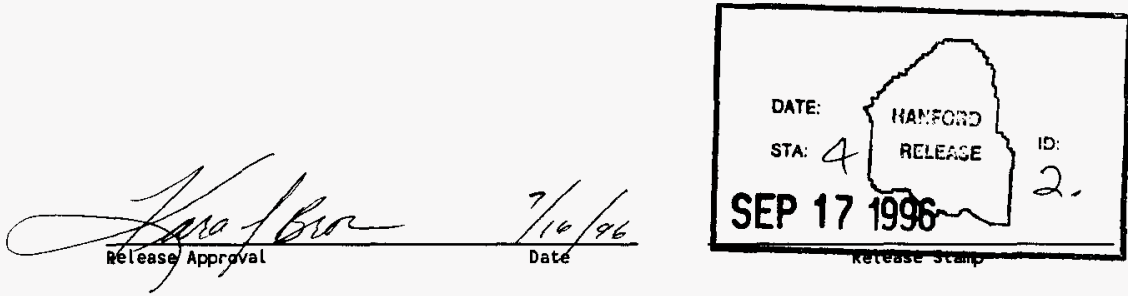

Approved for Public Release 
WHC-SD-SNF-DB-012, Rev. 0

\section{SLUDGE REMOVAL PROJECT WEASEL PIT REQUIREMENTS}

September 1996

D. R. Precechtel

S. A. Brisbin

M. A. Jensen

R. A. Schwarz 
WHC-SD-SNF-DB-012, Rev. 0

\section{TABLE OF CONTENTS}

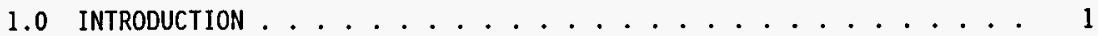

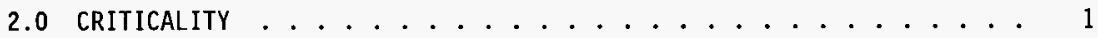

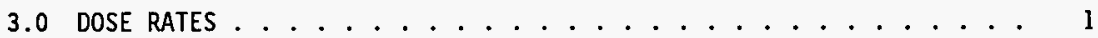

4.0 gAS EVOLUTION IN THE WEASEL PIT .............. 2

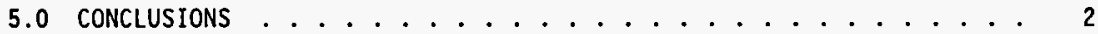

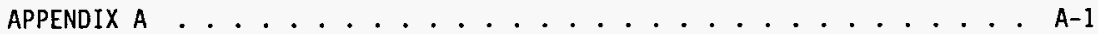

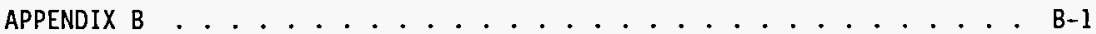

APPENDIX $c \ldots \ldots \ldots \ldots \ldots \ldots \ldots$

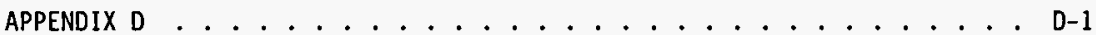

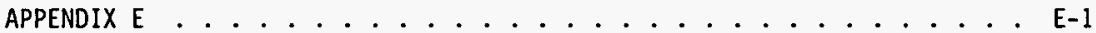


WHC-SD-SNF-DB-012, Rev. 0

SLUDGE REMOVAL PROJECT

SLUDGE MANAGEMENT REQUIREMENTS

\subsection{INTRODUCTION}

The $105 \mathrm{~K}$ East Basin fuel storage pool contains about $50 \mathrm{~m} 3$ of sludge. Current plans call for retrieval of this sludge to the Weasel Pit for storage and then transport to a Tank Waste Remediation System (TWRS) double-shell tank (DST) in the year 2000. Storage of this sludge in the Weasel Pit must accommodate concerns for:

- Criticality

- Shielding

- Operator dose commitment

- Gas evolution

These factors will influence how the sludge is stored, moved, and transported. The technical requirements on the Sludge Removal System accommodate these concerns are compiled herein.

\subsection{CRITICALITY}

The sludge stored in the Weasel Pit is critically safe due to the geometry and restrictions on fuel particle size. The width of the Weasel Pit (5' $6^{\prime \prime}$ ) is less than the infinite slab thickness required to achieve at $K$ effective of 0.98 with uniform dispersion of $1.28 \mathrm{~cm}(0.5$ inch) diameter fuel particles. Sludge was passed through a $0.64 \mathrm{~cm}(0.25$ inch) screen when transferred into the Weasel Pit. Extensive sampiing in the Weasel Pit and the main basin has not revealed any particles larger than $254 \mu \mathrm{m}$ (10 $\mathrm{mils}$ ). Corrosion of the fuel in the basin does not generate large fuel particles. Therefore, the Weasel Pit is considered critically safe for continuation of current practices. There are no limits on sludge depth in the Weasel Pit due to criticality limits. These conclusions are based on the criticality review provided in Appendix A.

\subsection{DOSE RATES}

Sludge accumulations in the Weasel Pit have the potential to increase the dose to $K$ Basin operators and the particular, to operators working around the Weasel Pit. A clean water depth of $1.8 \mathrm{~m}(6 \mathrm{ft})$ over the sludge will assure no significant increase in dose to the operators. More significant is the dose from the cesium in the "clear water" over the sludge due to pumping in new sludge, debris removal activities, or anything that disturbs the sludge. Use of shielding and/or access restrictions should be considered when the sludge is disturbed. These conclusions are derived from the dose calculations provided in Appendix B. 
The dose from a pipe filled with siudge is sufficiently high to warrant use of shielding and/or access restrictions when pumping sludge through above water piping/hose. Any submerged pipe or hose containing sludge should be at least $0.9 \mathrm{~m}(3 \mathrm{ft})$ underwater to avoid contributing to operator dose. These conclusions are derived from the dose calculations provided in Appendix C.

\subsection{GAS EVOLUTION IN THE WEASEL PIT}

Observation on unacceptable gas retention behavior from under thick layers of sludge in TWRS tanks has been applied to the Weasel Pit. As long as the sludge depth is not more than $5.5 \mathrm{~m}(11 \mathrm{ft})$, the data would suggest that significant flammable gas will not be trapped and subject to sudden release, with risk to the operators. These conclusions are derived from the analysis provided in Appendix D.

\subsection{CONCLUSIONS}

Sludge depths in the Weasel Pit should be maintained at less than $3.3 \mathrm{~m}$ (11 ft) both for dose management and gas retention concerns. The ability of $1.8 \mathrm{~m}(6 \mathrm{ft})$ of water over $3.3 \mathrm{~m}(11 \mathrm{ft})$ of sludge to successfully settle sludge and not result in excess doses at the surface has yet to be demonstrated.

Piping and hoses containing sludge should be maintained under at least $0.9 \mathrm{~m}(3 \mathrm{ft})$ of water to avoid any significant operator dose commitment.

The sludge management $\mathrm{plans}$ discussed in Appendix $\mathrm{E}$ suggest the need to use both the Weasel Pit and the Weasel Pit channel to store siudge to meet the above requirements. 
WHC-SD-SNF-DB-012, Rev. 0

\author{
APPENDIX A \\ CRITICALITY \\ M. A. Jensen
}


WHC-SD-SNF-DB-012, Rev. 0

Westinghouse Hanford Company

Internal : Memo

From: $\quad$ Standards and Requilrements

Phone: $373-1353 \times 3-79$

Date: July 11, 1996

Subject: K EAST WEASEL PIT SLUDGE

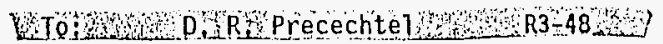

$\begin{array}{lll}\text { cc: } & \text { C. L. Bennett } & \times 3-79 \\ & \text { C. DeFigh-Price } & \times 3-79 \\ \text { J. C. Hamrick } & \times 3-71 \\ \text { D. O. Hess } & \times 3-80 \\ \text { SNF Project Files } & \text { R3-11 } \\ \text { MAJ File/LB } & X 3-79\end{array}$

Reference 1: Wittekind, W. D. 1993, MCNP Calculat lons of K-Infinity for 100KE Basin Sludge Samples, WHC-SD-NR-CSER-008 Rev 1, . Westinghouse Hanford Company, RIchland, WA.

I have performed a critfcality safety review of the proposed extension of the volume of the weasel pit avallable for receiving sludge pumped from the main basin.

Appendix A of Reference 1 modeled the weasel pit as an infinite slab composed of $3.0 \mathrm{~g} / \mathrm{cm}^{3} 0.95 \mathrm{wt} \% \mathrm{UO}_{2}$ sludge with embedded 0.25 inch $0.95 \mathrm{wt} \%$ uranium rods. The sludge density and lattice spacing of the rods within the sludge were chosen to maximize reactivity. This model is conservative because the enrichment chosen does not take credit for burnup, ignores the presence of fission products which may act as neutron poisons, and because actual weasel pit sludge density is not optimum. It was found that a slab infinite in two dimensions and imited to a height of 69 inches would have a multiplication factor $\left(k_{\text {eff }}\right)$ less than the limiting value of 0.98 . The weasel pit dimensions are $32^{\prime} 8^{\prime \prime}$ in length, $5^{\prime} 6^{\prime \prime}$ in width $\left(66^{\prime \prime}\right)$, and approximately $20^{\prime}$ deep. The reference stated that with the finite dimensions of the weasel pit, no slab height could attain a $k_{\text {eff }}=0.98$.

The existing analysis from Reference 1 wt.ll remain bounding if the length of the weasel pit used for sludge: retention is extended from the current sludge screen (approximately $24 \mathrm{feet}$ ) out to the basin entrance (approximateiy $\left.32^{\prime} 8^{\prime \prime}\right)$. This is because the maximum width of the wease $\mathrm{p}$ 1t is 66 inches; which is less than the slab height of 69 inches. The other two dimensions (32' 8 " length and approximately 20 feet depth) are the two "infinite" dimensions. The pit is modeled as an infinite vertical slab, with the pit width being the limiting dimension. 
D. R. Precechtel

$2 A 100-96.038$

Page 2

July 11, 1996

Sludge from any location in the K East basin may be pumped to the weasel pit without any restrictions beyond limiting the size of uranium pieces to 0.25 inches in diameter or less. This authorization does not apply to $\mathrm{K}$ West, which has not had an analysis of its potentially higher-enriched sludge.

If you have any questions please contact me on 373-1353.

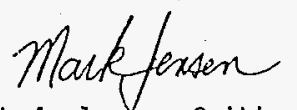

M. A. Jensen, Criticality Safety Representative Standards and Requirements

\section{Concurrence:}

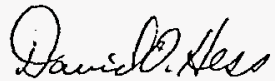

D. 0 . Hess

Spent Nuclear Fuel Project Safety

skr 
WHC-SD-SNF-DB-012, Rev. 0

APPENDIX B

WEASEL PIT RATES

R. A. Schwarz

B-1 
WHC-SD-SNF-DB-012, Rev. 0

Westinghouse

Internal

Hanford Company

Memo

From: Criticality and Shielding

Phone: $\quad 376-5977$ HO-35

Date: July 17, 1996

Subject: ,DOSE RATES IN THE K BASIN WEASEL PIT

To:

D. R. Precechtel

$x=85 \kappa 3-48$

cC:
C. J. Alderman
R3-48
K. H. Bergsman
R3-48
J. Greenborg
$\mathrm{HO}-35$
G. S. Hunacek
$\times 3-79$
J. S. Lan
$\mathrm{HO}-35$
T. D. Merkling
R3-09
F. W. Moore
$\times 3-85$
F. J. Muller
$\times 3-85$
A. L. Ramble
HO- 35
D. L. Schifferl
RAS File/LB
$\times 3-74$
HO-35

8M730-RAS-96-005

Attached is the dose rate calculation for sludge contained in the $\mathrm{K}$ Bas in Weasel Pit. Also attached to this document is the review checklist for the shielding analys is that has been filled out by the reviewer. It is understood that this information will be placed directly into a supporting document without any changes.

Ma scheras

R. A. Schwarz Advanced Scientist

$11 \mathrm{p}$

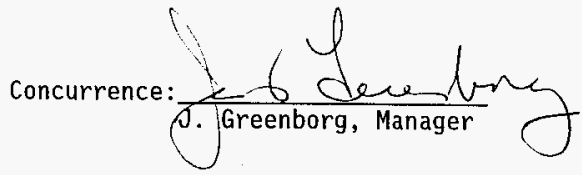

Attachments 
WHC-SD-SNF-DB-012, Rev. 0

8M730-RAS-96-005

ATTACHMENT 1

Page 1 of 18

Dose Rates in the $\mathrm{K}$ Basin Wease] Pit

R. A. Schwarz

Juty 1996 
Dose rate calculations have been made for sludge and activated water contained in the Weasel Pit at $K$ Basin as requested by the document in reference 1 . Dose rates were calculated for sludge covered with water, where the source in the water source consists of either standing water or water that has been agitated by pumping. Figure 1 shows a diagram of the shielding configuration and the location of the dose points. The total depth of the siudge and water is 17 feet. The sludge depth was varied from 0 to 17 feet with water filling in on top of the sludge to maintain a constant sludge/water depth of 17 feet. Dose rates were calculated at $18 \mathrm{in}$. and $48 \mathrm{in}$. above the floor grate. The floor grate is 4 feet above the top of the water. All dose rate calculations were made using the Isoshld-PC computer code (Reference 2).

2.0

SUMMARY

Table 1 summarizes the dose rates at $18 \mathrm{in.}$ above the grate. Table 2 summarizes the dose rates at $48 \mathrm{in}$. above the grate. When there is 6 feet or more of water above the sludge, the dose rate is dominated by the water source term which will produce a dose rate of $0.8 \mathrm{mrem} / \mathrm{hr}$ at 18 in. for standing water and a dose rate of $7 \mathrm{mrem} / \mathrm{hr}$ at $18 \mathrm{in}$. for agitated water. When the amount of water above the sludge is less than 6 feet, the sludge dose rates will start to dominate the dose rate. For the worst case conditions of 17 feet of sludge, the dose rate at $18 \mathrm{in}$. is $31.5 \mathrm{rem} / \mathrm{hr}$ and at $48 \mathrm{in}$. is 21.5 $\mathrm{rem} / \mathrm{hr}$.

Figure 2 shows a plot of the dose rates at $18 \mathrm{in.}$ above the grate as a function of water, depth. Both the individual contributions to the dose rate and the total sludge and water dose rate is plotted. Figure 3 shows a plot of the dose rates at 48 in. above the grate.

\subsection{SOURCE}

The source for the sludge was obtained from Table 4.3 of Reference 3 . The mean values listed in this table was used for the sludge source. For cases where a mean value is not listed, the average of the maximum and minimum value was used. Table 3 lists the isotopic inventories (microcuries/cc) used for the sludge source. A density of $1.4 \mathrm{~g} / \mathrm{cc}$ was used as 1 isted in Table 4.2 of Reference 3 (density of $1.39 \mathrm{~g} / \mathrm{cc}$ ).

The source term for the water before and during the pumping of the water was obtained from Reference 4. Values were estimated from the histogram plots in this reference. The values for inside the Weasel Pit Screen were used. Table 4 lists the isotopic inventory (microcuries/cc) for the water before pumping. Table 5 lists the isotopic inventories while pumping (microcuries/cc).

It is conservatively assumed in Tables 3,4 and 5 that the ${ }^{137 \mathrm{~m}} \mathrm{Ba}$ content is equal to the amount of ${ }^{137} \mathrm{Cs}$. For Table 3 the ${ }^{90} \mathrm{Y}$ content is set equal to the ${ }^{90} \mathrm{Sr}$ content.

\subsection{DOSE RATE AS A FUNCTION OF CESIUM 137 CONTENT IN THE WATER}

Table 6 lists the dose rates at $18 \mathrm{in}$. and $48 \mathrm{in}$. as a function of ${ }^{137} \mathrm{Cs}$ content in the water. Figure 4 shows a plot of the dose rates presented in 
Table 6. Notice that the dose rate scales with the ${ }^{137} \mathrm{Cs}$ content. Also shown in Figure 4 is the dose rate for both the standing water and agitated water (while pumping) at 18 in. above the grate. The water values are slightiy higher than the $18 \mathrm{in}$. dose rate line because of other isotopes present in the water.

\subsection{DOSE RATE FOR AN INFINITE WATER SOURCE}

As an independent check, a dose rate calculation was made for a simulated infinite water source term. The source was modeled as $100,000 \mathrm{~cm}$. by 100,000 $\mathrm{cm}$. with a depth of $6 \mathrm{ft}$. The dose rate calculated at $18 \mathrm{in}$. was $3.05 \mathrm{mrem} / \mathrm{hr}$ and at $48 \mathrm{in}$. was $2.98 \mathrm{mrem} / \mathrm{hr}$. This value compares well with current dose rate measurements above the $\mathrm{K}$ Basin water.

Notice that in Table 1 , for $6 \mathrm{ft}$. of water, the dose rate is $0.768 \mathrm{mrem} / \mathrm{hr}$. This dose rate is lower than the infinite case because of the dimensions of the Weasel Pit.

\subsection{DOSE RATE CALCULATIONS}

Table 7 lists summarizes all of the dose rate calculations made, the name of the input file and the Appendix that contains the input file.

The Weasel Pit was modeled as a rectangular solid with a width of $167.6 \mathrm{~cm}$ and a length of $995.7 \mathrm{~cm}$. These dimensions are more conservative than the dimensions for the actual Weasel Pit which is irregularly shaped. In all cases, the dose rate is dominated by the ${ }^{137} \mathrm{Cs}$. For the worst dose rate case of $17 \mathrm{ft}$. of sludge, $93 \%$ of the dose rate is from ${ }^{137} \mathrm{Cs}$.

\subsection{REFERENCES}

1. Memo, D. R. Precehtel to R. A. Schwarz, "Work Scope for the K Basin Weasel Pit Dose Rate Analysis," dated June 10, 1996.

2. P. D. Rittman, "ISO-PC Version 1.98 - User's Guide," WHC-SD-WM-UM030, Rev. 0, 1995.

3. B. J. Makenas, editor, "Analysis of Sludge form Hanford K East Basin Floor and Weasel Pit," WHC-SP-1182, May 1996.

4. Memo, J. Mancilla, "KE Weasel Pit Water Sample Results," dated May $10,1996$. 
WHC-SD-SNF-DB-012, Rev. 0

8M730-RAS-96-005

ATTACHMENT 1

Page 4 of 18

Table 1. Dose Rate at 18 in. Above the Grate

\begin{tabular}{|c|c|c|c|c|c|c|}
\hline \multirow{2}{*}{$\begin{array}{l}\text { Water } \\
\text { depth } \\
\text { (feet) }\end{array}$} & \multirow{2}{*}{$\begin{array}{l}\text { Sludge } \\
\text { depth } \\
\text { (feet) }\end{array}$} & \multicolumn{5}{|c|}{ Dose Rate (mrem/hr) } \\
\hline & & $\begin{array}{c}\text { Water } \\
\text { Before } \\
\text { Pumping } \\
\end{array}$ & $\begin{array}{c}\text { Water } \\
\text { During } \\
\text { Pumping } \\
\end{array}$ & Sludge & $\begin{array}{c}\text { Water } \\
\text { Before + } \\
\text { sludge } \\
\end{array}$ & $\begin{array}{c}\text { Water } \\
\text { During + } \\
\text { Sludge } \\
\end{array}$ \\
\hline 17.0 & 0.00 & $7.68 \mathrm{e}-01$ & $6.93 e+00$ & 0.00 & $7.68 \mathrm{e}-01$ & $6.93 e+00$ \\
\hline 8.5 & 8.50 & $7.68 \mathrm{e}-01$ & $6.93 e+00$ & $2.96 \mathrm{e}-04$ & $7.68 \mathrm{e}-01$ & $6.93 e+00$ \\
\hline 7.5 & 9.50 & $7.68 \mathrm{e}-01$ & $6.93 e+00$ & $1.96 \mathrm{e}-03$ & $7.70 \mathrm{e}-01$ & $6.93 e+00$ \\
\hline 6.5 & 10.50 & $7.68 \mathrm{e}-01$ & $6.93 \mathrm{e}+00$ & $1.47 e-02$ & $7.82 \mathrm{e}-01$ & $6.94 \mathrm{e}+00$ \\
\hline 6.0 & 11.00 & $7.68 \mathrm{e}-01$ & $6.93 \mathrm{e}+00$ & $4.23 e-02$ & $8.10 \mathrm{e}-01$ & $6.97 e+00$ \\
\hline 5.5 & 11.50 & $7.68 \mathrm{e}-01$ & $6.92 \mathrm{e}+00$ & $1.25 \mathrm{e}-01$ & $8.93 e-01$ & $7.05 \mathrm{e}+00$ \\
\hline 4.5 & 12.50 & $7.68 \mathrm{e}-01$ & $6.92 \mathrm{e}+00$ & $1.17 \mathrm{e}+00$ & $1.94 \mathrm{e}+00$ & $8.10 \mathrm{e}+00$ \\
\hline 3.5 & 13.50 & $7.67 \mathrm{e}-01$ & $6.92 e+00$ & $1.18 \mathrm{e}+01$ & $1.25 \mathrm{e}+01$ & $1.87 \mathrm{e}+01$ \\
\hline 2.5 & 14.50 & $7.65 \mathrm{e}-01$ & $6.89 e+00$ & $1.23 \mathrm{e}+02$ & $1.23 \mathrm{e}+02$ & $1.29 \mathrm{e}+02$ \\
\hline 1.5 & 15.50 & $7.36 e-01$ & $6.62 \mathrm{e}+00$ & $1.28 \mathrm{e}+03$ & $1.28 \mathrm{e}+03$ & $1.29 e+03$ \\
\hline 0.5 & 16.50 & $4.63 e-01$ & $4.15 e+00$ & $1.25 \mathrm{e}+04$ & $1.25 \mathrm{e}+04$ & $1.25 \mathrm{e}+04$ \\
\hline 0.0 & 17.00 & 0.00 & 0.00 & $3.15 e+04$ & $3.15 e+04$ & $3.15 e+04$ \\
\hline
\end{tabular}


WHC-SD-SNF-DB-012, Rev. 0

8M730-RAS-96-005

ATTACHMENT 1

Page 5 of 18

Table 2. Dose Rate at 48 in. Above the Grate

\begin{tabular}{|r|c|c|c|c|c|c||}
\hline \multirow{2}{*}{$\begin{array}{c}\text { Water } \\
\text { depth } \\
\text { (feet) }\end{array}$} & \multirow{2}{*}{$\begin{array}{c}\text { Sludge } \\
\text { depth } \\
\text { (feet) }\end{array}$} & $\begin{array}{c}\text { Water } \\
\text { Before } \\
\text { Pumping }\end{array}$ & $\begin{array}{c}\text { Water } \\
\text { During } \\
\text { Pumping }\end{array}$ & Sludge & $\begin{array}{c}\text { Water } \\
\text { Before }+ \\
\text { Sludge }\end{array}$ & $\begin{array}{c}\text { Water } \\
\text { During }+ \\
\text { Sludge }\end{array}$ \\
\hline \hline 17.0 & 0.00 & $5.25 \mathrm{e}-01$ & $4.73 \mathrm{e}+00$ & 0.00 & $5.25 \mathrm{e}-01$ & $4.73 \mathrm{e}+00$ \\
\hline 8.5 & 8.50 & $5.25 \mathrm{e}-01$ & $4.73 \mathrm{e}+00$ & $2.58 \mathrm{e}-04$ & $5.25 \mathrm{e}-01$ & $4.73 \mathrm{e}+00$ \\
\hline 7.5 & 9.50 & $5.25 \mathrm{e}-01$ & $4.73 \mathrm{e}+00$ & $1.69 \mathrm{e}-03$ & $5.26 \mathrm{e}-01$ & $4.73 \mathrm{e}+00$ \\
\hline 6.5 & 10.50 & $5.25 \mathrm{e}-01$ & $4.73 \mathrm{e}+00$ & $1.26 \mathrm{e}-02$ & $5.37 \mathrm{e}-01$ & $4.75 \mathrm{e}+00$ \\
\hline 6.0 & 11.00 & $5.25 \mathrm{e}-01$ & $4.73 \mathrm{e}+00$ & $3.60 \mathrm{e}-02$ & $5.61 \mathrm{e}-01$ & $4.77 \mathrm{e}+00$ \\
\hline 5.5 & 11.50 & $5.25 \mathrm{e}-01$ & $4.73 \mathrm{e}+00$ & $1.06 \mathrm{e}-01$ & $6.30 \mathrm{e}-01$ & $4.84 \mathrm{e}+00$ \\
\hline 4.5 & 12.50 & $5.25 \mathrm{e}-01$ & $4.73 \mathrm{e}+00$ & $9.78 \mathrm{e}-01$ & $1.50 \mathrm{e}+00$ & $5.71 \mathrm{e}+00$ \\
\hline 3.5 & 13.50 & $5.24 \mathrm{e}-01$ & $4.73 \mathrm{e}+00$ & $9.65 \mathrm{e}+00$ & $1.02 \mathrm{e}+01$ & $1.44 \mathrm{e}+01$ \\
\hline 2.5 & 14.50 & $5.22 \mathrm{e}-01$ & $4.71 \mathrm{e}+00$ & $9.83 \mathrm{e}+01$ & $9.88 \mathrm{e}+01$ & $1.03 \mathrm{e}+02$ \\
\hline 1.5 & 15.50 & $5.00 \mathrm{e}-01$ & $4.50 \mathrm{e}+00$ & $9.94 \mathrm{e}+02$ & $9.95 \mathrm{e}+02$ & $9.99 \mathrm{e}+02$ \\
\hline 0.5 & 16.50 & $3.03 \mathrm{e}-01$ & $2.71 \mathrm{e}+00$ & $9.04 \mathrm{e}+03$ & $9.04 \mathrm{e}+03$ & $9.04 \mathrm{e}+03$ \\
\hline 0.0 & 17.00 & 0.00 & 0.00 & $2.15 \mathrm{e}+04$ & $2.15 \mathrm{e}+04$ & $2.15 \mathrm{e}+04$ \\
\hline
\end{tabular}


WHC-SD-SNF-DB-012, Rev. 0

8M730-RAS-96-005

ATTACHMENT 1

Page 6 of 18

Table 3. Sludge Source Term (microcuries/cc)

\begin{tabular}{|c|c|}
\hline Isotope & Amount (microcuries/cc) \\
\hline Co 60 & $9.43 \mathrm{E}-1$ \\
\hline Sr 90 & $1.79 E+2$ \\
\hline Y $90^{1}$ & $1.79 \mathrm{E}+2$ \\
\hline $\mathrm{Nb} 94$ & $2.31 E-1$ \\
\hline Ru 106 & $8.61 E+0$ \\
\hline Rh 106 & $8.61 \mathrm{E}+0$ \\
\hline Sb 125 & $1.89 \mathrm{E}+0$ \\
\hline Cs 134 & 4. $61 \mathrm{E}-1$ \\
\hline Cs 137 & $2.11 E+2$ \\
\hline Ba $137 \mathrm{~m}^{2}$ & $2.11 E+2$ \\
\hline Ce 144 & $5.90 \mathrm{E}+0$ \\
\hline $\operatorname{Pr} 144$ & $5.90 \mathrm{E}+0$ \\
\hline Eu 152 & $3.58 \mathrm{E}-1$ \\
\hline Eu 154 & $1.59 \mathrm{E}+0$ \\
\hline Eu 155 & 7.19E-1 \\
\hline Bi 212 & $1.81 \mathrm{E}+0$ \\
\hline $\operatorname{Ra} 226$ & $1.13 \mathrm{E}+1$ \\
\hline U 233 & $2.03 E-2$ \\
\hline U 234 & $2.44 \mathrm{E}-2$ \\
\hline U 235 & $7.91 \mathrm{E}-4$ \\
\hline U 238 & $1.73 \mathrm{E}-2$ \\
\hline Np 237 & $1.41 \mathrm{E}-3$ \\
\hline $\mathrm{Pu} 238$ & $8.62 \mathrm{E}-1$ \\
\hline Pu 239 & $8.88 \mathrm{E}+0$ \\
\hline Pu 240 & $8.88 \mathrm{E}+0$ \\
\hline Am 241 & $8.98 E+0$ \\
\hline $\mathrm{Cm} 243$ & $6.46 \mathrm{E}+0$ \\
\hline $\mathrm{Cm} 244$ & $6.46 \mathrm{E}+0$ \\
\hline Total & $=$ \\
\hline
\end{tabular}


IHC-SD-SNF-DB-012, Rev. 0

8M730-RAS-96-005

ATTACHMENT 1

Page 7 of 18

Table 4. Source Term for Water Before Pumping (microcuries/cc)

\begin{tabular}{|c|c|}
\hline Isotope & Amount (microcuries/cc) \\
\hline \hline Co 60 & $1.0 \mathrm{E}-5$ \\
\hline Cs 134 & $1.2 \mathrm{E}-6$ \\
\hline Cs 137 & $4.0 \mathrm{E}-3$ \\
\hline Ba $137 \mathrm{~m}^{1}$ & $4.0 \mathrm{E}-3$ \\
\hline Eu 154 & $1.0 \mathrm{E}-5$ \\
\hline Eu 155 & $1.0 \mathrm{E}-5$ \\
\hline Total & $8.0 \mathrm{E}-3$ \\
\hline Assumed equal to
\end{tabular}

Table 5. Source Term for Water While Pumping (microcuries/cc)

\begin{tabular}{|c|c|}
\hline Isotope & Amount (microcuries/cc) \\
\hline Co 60 & $6.4 \mathrm{E}-4$ \\
\hline Cs 134 & $5.8 \mathrm{E}-6$ \\
\hline Cs 137 & $3.3 \mathrm{E}-2$ \\
\hline Ba $137 \mathrm{~m}^{1}$ & $3.3 \mathrm{E}-2$ \\
\hline Eu 154 & $6.9 \mathrm{E}-4$ \\
\hline Eu 155 & $5.0 \mathrm{E}-4$ \\
\hline Total & $7.6 \mathrm{E}-2$ \\
\hline
\end{tabular}


WHC-SD-SNF-DB-012, Rev. 0

8M730-RAS-96-005

ATTACHMENT 1

Page 8 of 18

Table 6. Dose Rate as a function of Cs 137 content.

\begin{tabular}{|c|c|c|}
\hline \multirow{2}{*}{$\begin{array}{c}\text { Amount of }{ }^{137} \mathrm{Cs} \\
\text { (microcuries } / \mathrm{L})\end{array}$} & \multicolumn{2}{|c|}{ Dose Rate (mrem/hr) } \\
\cline { 2 - 3 } & $18 \mathrm{in}$ & $48 \mathrm{in}$. \\
\hline 1 & 0.020 & 0.014 \\
\hline 10 & 1.90 & 1.30 \\
\hline 20 & 3.80 & 2.59 \\
\hline 30 & 5.69 & 3.89 \\
\hline 40 & 7.58 & 5.18 \\
\hline 50 & 9.47 & 6.47 \\
\hline 60 & 11.4 & 7.76 \\
\hline 70 & 13.3 & 9.06 \\
\hline 80 & 15.2 & 10.4 \\
\hline 90 & 17.0 & 11.6 \\
\hline 100 & 18.9 & 12.9 \\
\hline
\end{tabular}

Table 7. Isoshld-PC Input Files.

\begin{tabular}{|c|c|c|}
\hline File Name & Description & Appendix \\
\hline water. in & $\begin{array}{l}\text { Dose rates from water before pumping. Water depth. } \\
\text { varied from } 0.5 \mathrm{ft} \text {. to } 17 \mathrm{ft} \text {. }\end{array}$ & A \\
\hline pump. in & $\begin{array}{l}\text { Dose rates from water while pumping. Water depth } \\
\text { varied from } 0.5 \mathrm{ft} \text {. to } 7 \mathrm{ft} \text {. }\end{array}$ & $B$ \\
\hline sldg. in & $\begin{array}{l}\text { Dose rates from the sludge with a water shield } \\
\text { above the sludge. Sludge depth varied from } 8.5 \\
\mathrm{ft} \text {. to } 16.5 \mathrm{ft} \text {. }\end{array}$ & c \\
\hline al1sidg.in & Dose rates from $17 \mathrm{ft}$. of sludge. & $\mathrm{D}$ \\
\hline waterinf.in & $\begin{array}{l}\text { Dose Rates from a } 100,000 \mathrm{~cm} \text {. by } 1000,000 \mathrm{~cm} \text {. } \\
\text { water source. }\end{array}$ & $\mathrm{E}$ \\
\hline csrange. in & $\begin{array}{l}\text { Dose rate as a function of }{ }^{137} \mathrm{Cs} \text { content. }{ }^{137} \mathrm{Cs} \\
\text { varied from } 1 \text { microcurie/L to } 100 \text { microcuries } / \mathrm{L} \text {. }\end{array}$ & $\mathrm{F}$ \\
\hline
\end{tabular}


WHC-SD-SNF-DB-012, Rev. 0

8M730-RAS-96-005

ATTACHMENT 1

Page 9 of 18

Figure 1. Figure Showing Shielding Configuration and Dose Points

- Dose Rate 48 in. Above the Grate

- Dose Rate 18 in. Above the Grate

Grate

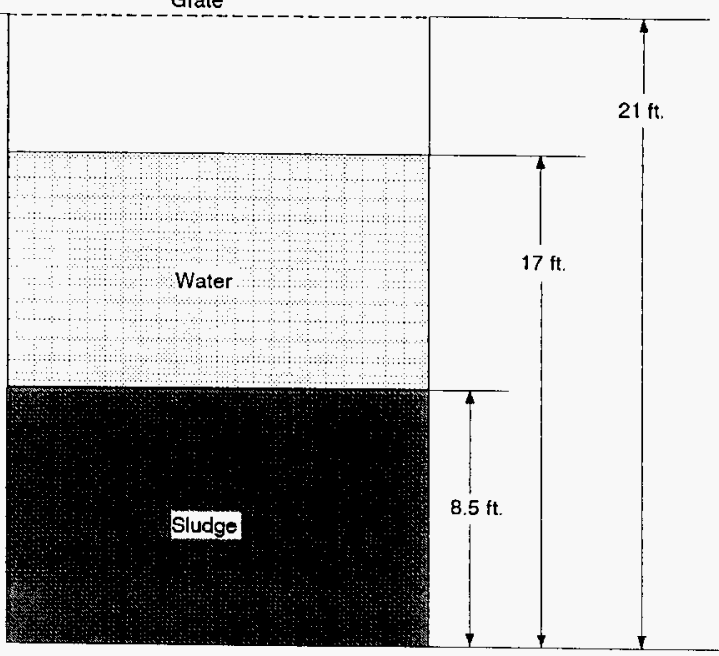




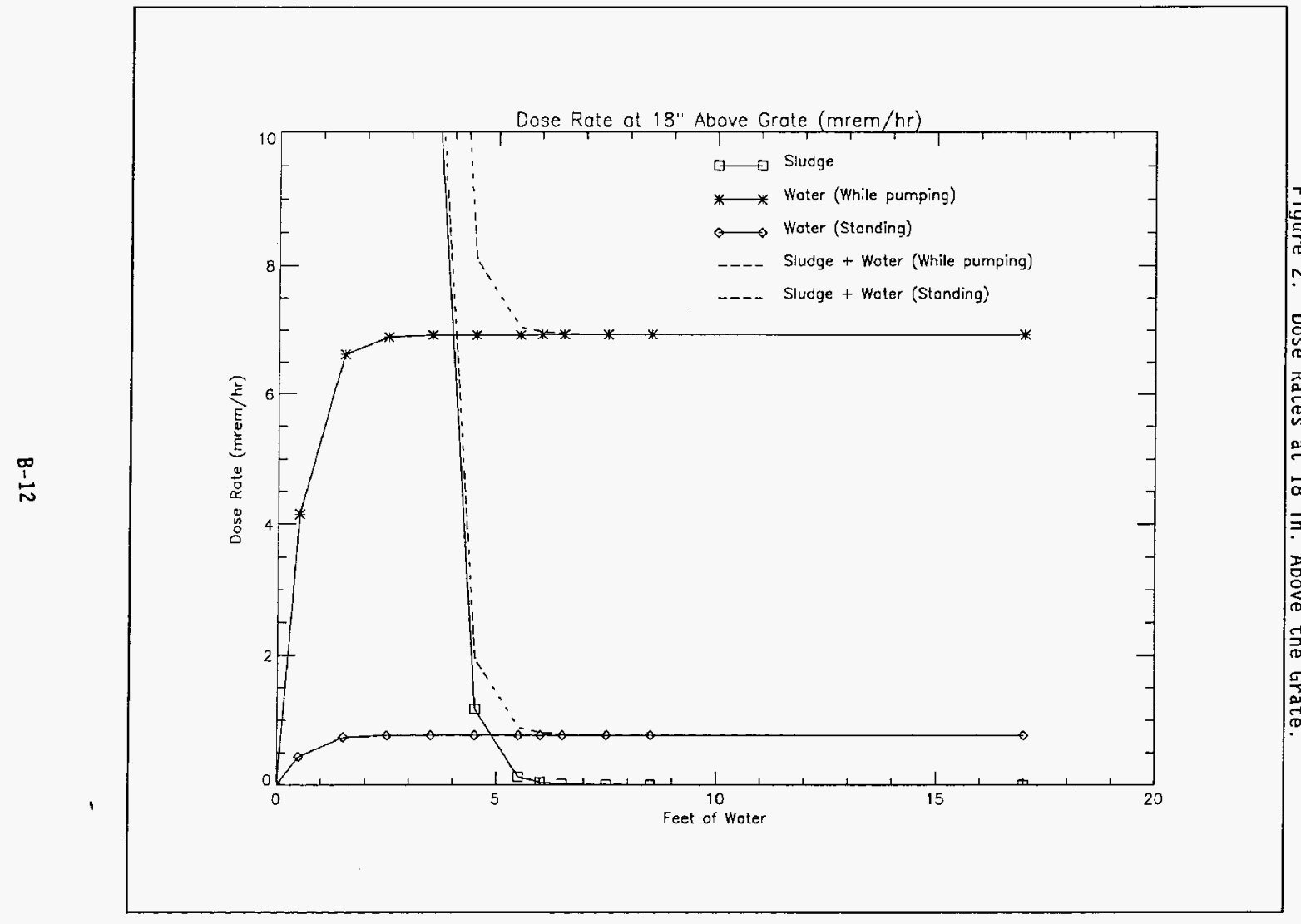


WHC-SD-SNF-DB-012, Rev. 0

8M730-RAS-96-005

ATTACHMENT 1

Page 11 of 18

Figure 3. Dose Rates at 48 in. Above the Grate.

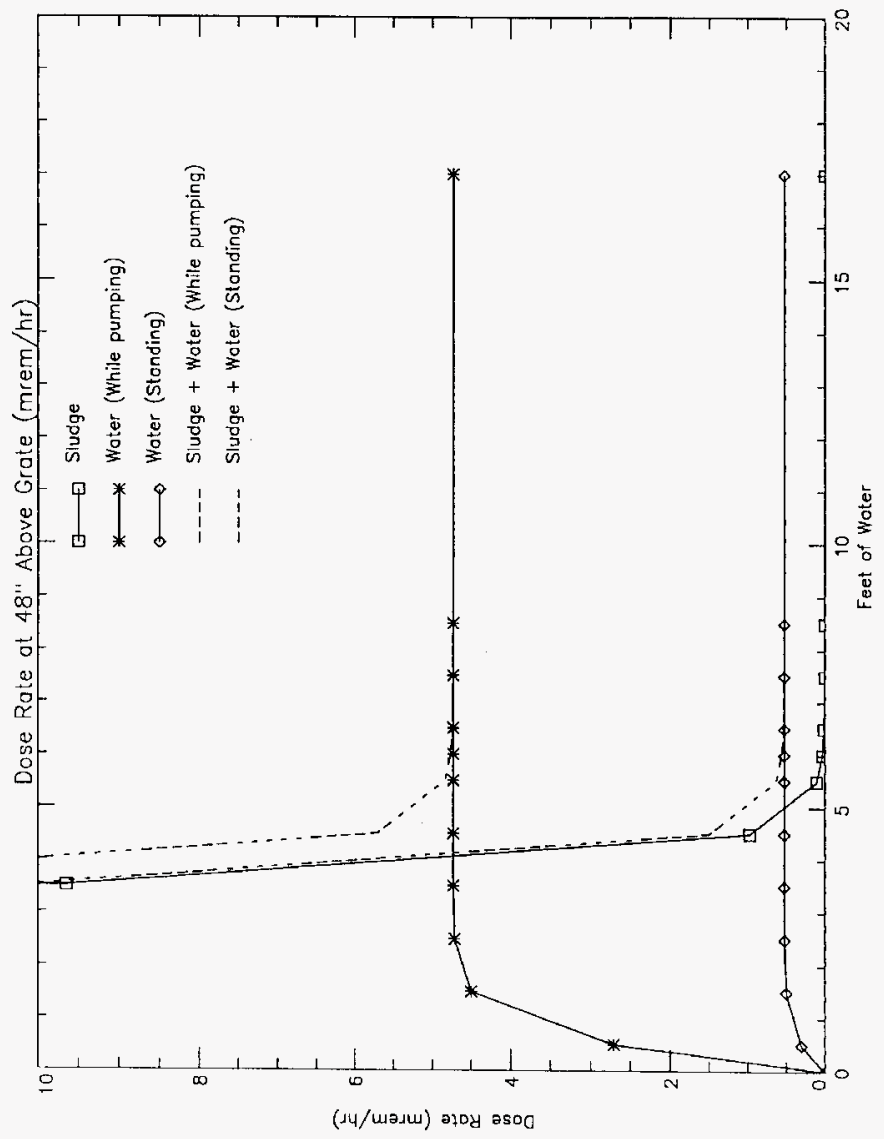


WHC-SD-SNF-DB-012, Rev. 0

8M730-RAS-96-005

ATTACHMENT 1

Page 12 of 18

Figure 4. Dose Rate as a Funcition of Cesium Content.

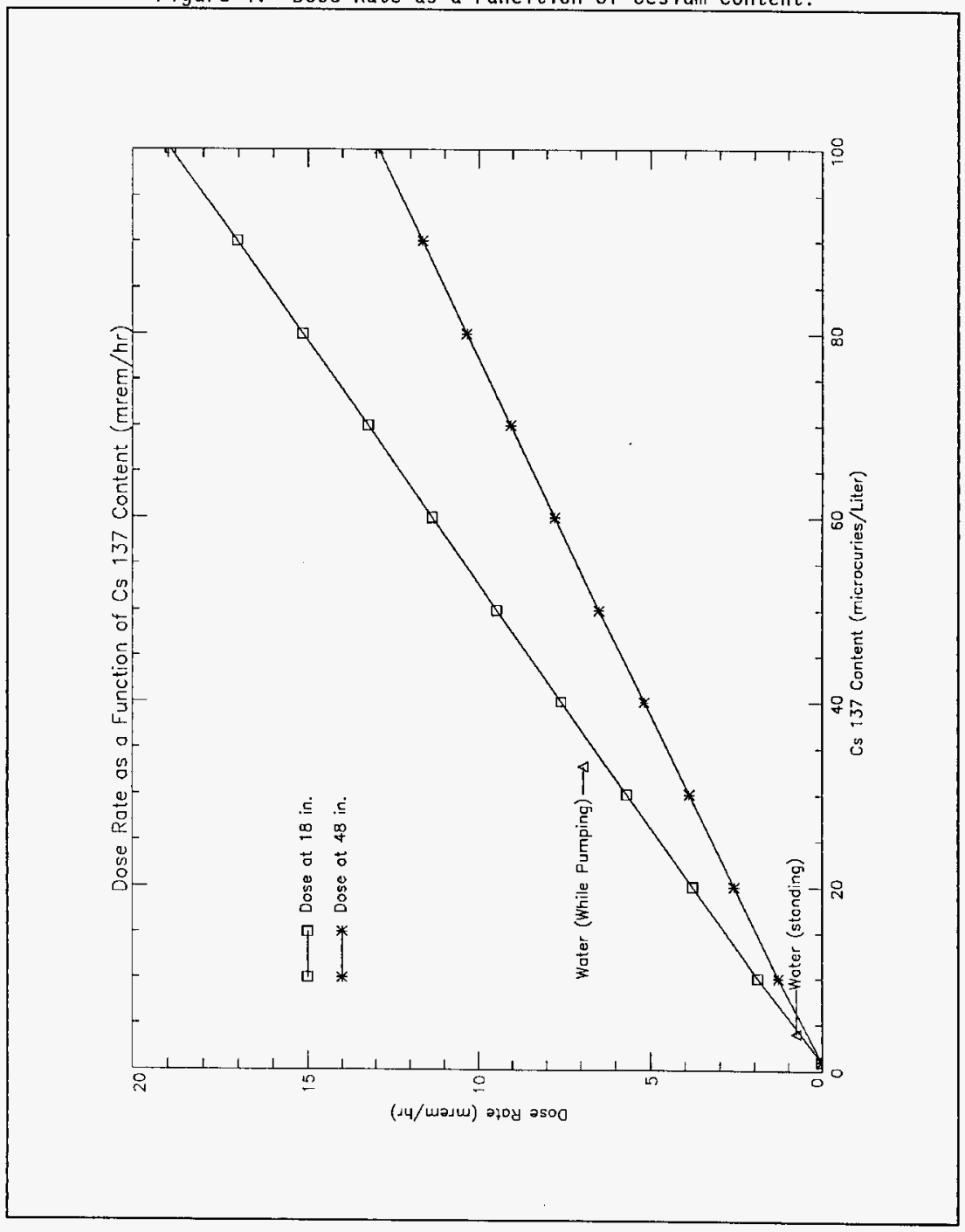


8M730-RAS-96-005

ATTACHMENT 1

Page 13 of 18

Appendix A. Isoshld-PC input file water.in

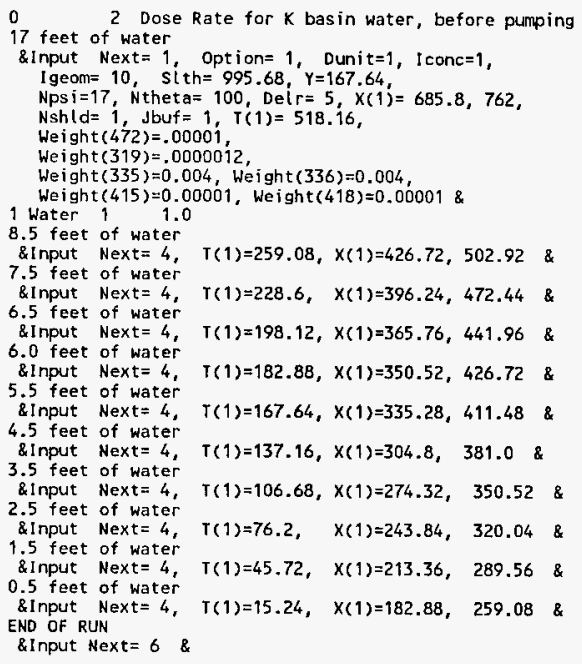


WHC-SD-SNF-DB-012, Rev. 0

8M730-RAS-96-005

ATTACHMENT 1

Page 14 of 18

Appendix B. Isoshld-PC input file pump.in

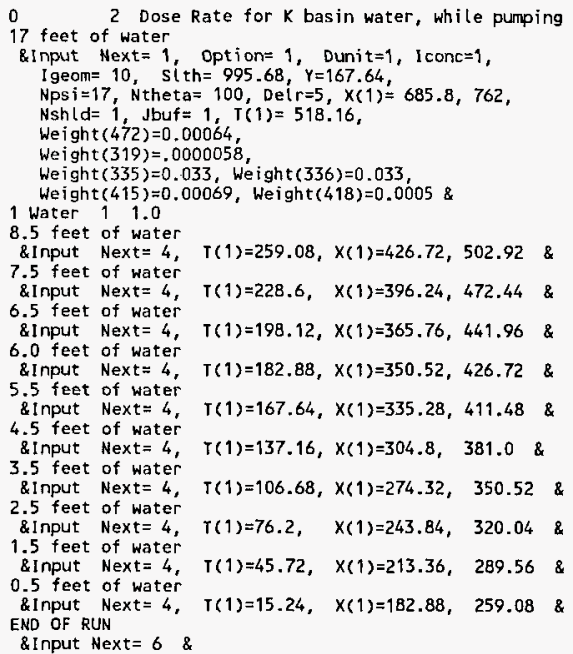


WHC-SD-SNF-DB-012, Rev. 0

8M730-RAS-96-005

ATTACHMENT 1

Page 15 of 18

Appendix C. Isoshld-PC input file sldg.in

022 Dose Rate for sludge, buildup in water

8.5 feet of sludge

Binput Next $=1$, option=1, Dunit $=1$, I conc=1,

I geom $=10, \mathrm{si}$ th $=995.68, Y=167.64$,

Nps $i=17$, N theta $=100$, Del $r=5, X(1)=685.8,762$,

Nshld $=2$, Jbuf $=2, T(1)=259.08, T(2)=259.08$

Weight $(472)=.943$,

Weight $(335)=211$, Weight $(336)=211$,

Weight $(319)=0.461$,

Weight $(415)=1.59$

We ight $(418)=0.719$,

Weight $(376)=5.897$, Weight $(377)=5.897$,

Weight (111) $=0.231$

Weight $(170)=8.614$, weight $(172)=8.614$,

Weight $(485)=11.3$

Weight $(525)=1.81$

Weight $(408)=0.358$,

Weight $(269)=1.89$

Weight $(496)=8.98$,

Weight $(493)=8.88$, Weight $(494)=8.88$,

Weight (492) $=0.862$

We ight $(502)=0.00141$

Weight $(506)=6.46$, Weight $(500)=6.46$,

Weight $(82)=179$, Weight $(84)=179$,

We igh $\mathrm{t}(519)=2.03 \mathrm{e}-2$,

Weight $(520)=2.44 e-2$,

Weight $(476)=7.91 \mathrm{e}-4$.

Weight $(526)=1.73 e-2 \&$

1 water 1 t.4 1.0

9.5 feet of sludge

\& Input Next $=4, T(1)=289.56, T(2)=228.60$ \&

10.5 feet of sludge

\&Input Next $=4, T(1)=320.04, T(2)=198.12$ \&

11.0 feet of sludge

\&input Next $=4, T(1)=335.28, T(2)=182.88$ \&

11.5 feet of sludge

\& I mput Next $=4, T(1)=350.52, T(2)=167.64 \&$

12.5 feet of sludge

\&Input Next $=4, T(1)=381.00, T(2)=137.16 \quad$ \&

13.5 feet of sludge

\&input Next $=4, T(1)=411.48, T(2)=106.68 \&$

14.5 feet of sludge

Qinput Next $=4, T(1)=441.96, T(2)=76.20$ \&

15.5 feet of sludge

\&input Next $=4, T(1)=472.44, T(2)=45.72$ \&

16.5 feet of sludge

\&Input Next $=4, T(1)=502.92, T(2)=15.24$ \&

END OF RUN

\&Input Next $=6$ \& 
WHC-SD-SNF-DB-012, Rev. 0

8M730-RAS-96-005

ATTACHMENT 1

Page 16 of 18

Appendix D. Isoshld-PC input file allsldg.in

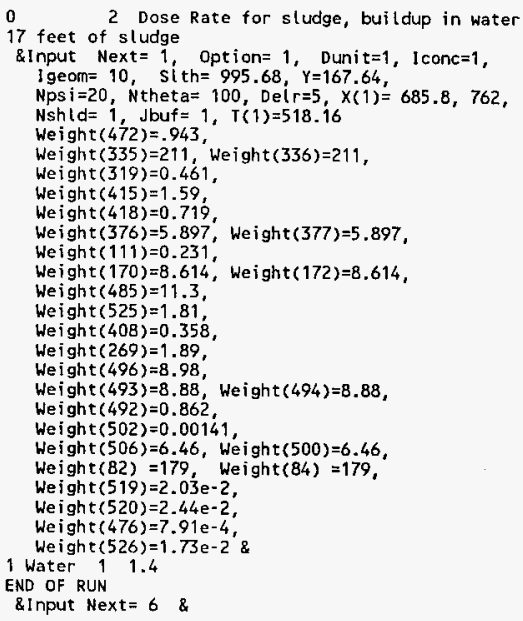




\section{Appendix E. Isoshld-PC input file waterinf.in}

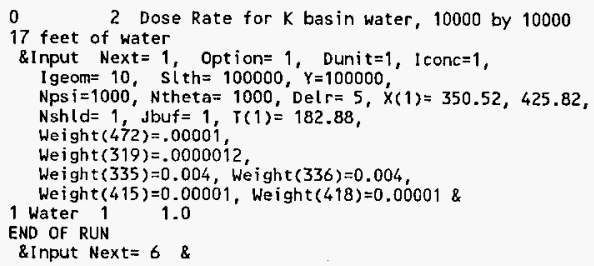


WHC-SD-SNF-DB-012, Rev. 0

8M730-RAS-96-005

ATTACHMENT 1

Page 18 of 18

Appendix F. Isoshld-PC input file csrange.in

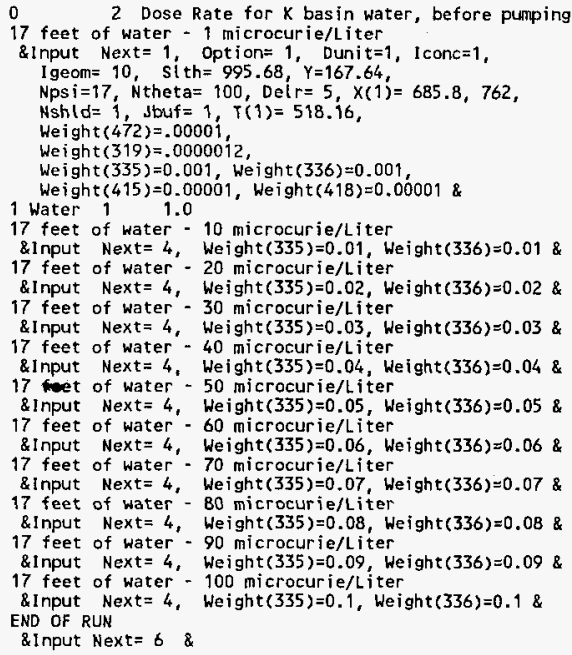


CHECKLIST FOR INDEPENDENT TECHNICAL REVIEW

NUMBER: 8M730-RAS-96-005

DOCUMENT REVIEWED Dose Rates in the $K$ Basin Wease 1 Pit

AUTHOR(s) R. A. Schwarz

I. Method(s) of Review

$(\checkmark)$ Input data checked for accuracy

$(\checkmark)$ Independent calculation performed

( ) Hand calculation

$(\checkmark)$ Alternate computer code: MCNP POINT KERNAL, MICROSHIELD

( ) Comparison to experiment or previous results

() Alternate method (define)

II. Checklist (either check or enter NA if not applied)

( $\checkmark$ ) Task completely defined

( $\checkmark$ Activity consistent with task specification

$(\checkmark)$ Necessary assumptions explicitly stated and supported

( $)$ Resources properly identified and referenced

( Resource documentation appropriate for this application

( $\checkmark$ Input data explicitly stated

( $\checkmark$ Input data verified to be consistent with original source

( Geometric model adequate representation of actual geometry

$(\checkmark)$ Material properties appropriate and reasonable

(NA) Mathematical derivations checked including dimensional consistency

(NA) Hand calculations checked for errors

( $\checkmark$ Assumptions explicitly stated and justified

( ) Computer software appropriate for task and used within range of validity

( $N A$ ) Use of resource outside range of established validity is justified

$(\checkmark)$ Software runstreams correct and consistent with results

$(\checkmark)$ Software output consistent with input

(NA) Results consistent with applicable previous experimental or analytical findings

( Results and conclusions address all points and are consistent with task requirements and/or established imits or criteria

(NA) Conclusions consistent with analytical results and established limits

(NA) Uncertainty assesment appropriate and reasonable

() other (define)

III. Comments:

IV. REVIEWER: 0/vikotiman DATE: 17 July 1996 
WHC-SD-SNF-DB-012, Rev. 0

APPENDIX C

SLUDGE PIPING DOSE RATES

R. A. Schwarz

C-1 
From: Criticality and Shielding

Phone: $376-5977$ HO-35

Date: August 5, 1996

Subject: DOSE RATES FOR SLUDGE INSIDE A PIPE

To:

D. R. Precechtel

$x 3<85 \times 3-48$

$\begin{array}{lll}\text { CC: } & \text { C. J. Alderman } & \text { R3-48 } \\ \text { K. H. Bergsman } & \text { R3-48 } \\ \text { J. Greenborg } & \text { H0-35 } \\ \text { G. S. Hunacek } & \text { X3-79 } \\ \text { T. D. Merk]ing } & \text { R3-09 } \\ \text { F. W. Moore } & \text { X3-85 } \\ \text { F. J. Muller } & \text { X3-85 } \\ \text { A. L. Ramble } & \text { A3-38 } \\ \text { D. L. Schifferl } & \text { X3-74 } \\ \text { RAS File/LB } & \text { H0-35 }\end{array}$

Attached is the dose rate calculation for sludge contained in a pipe. Also attached to this document is the review check7ist for the shielding analysis that has been filled out by the reviewer. It is understood that this information will be placed directly into a supporting document without any changes.

Ra beharaz

R. A. Schwarz

Advanced Scientist

$11 p$

Attachments 
WHC-SD-SNF-DB-012, Rev. 0

8M730-RAS-96-006

ATTACHMENT 1

Page 1 of 20

Dose Rates for Sludge inside a Pipe

R. A. Schwarz

August 1996

C-3 
WHC-SD-SNF-DB-012, Rev. 0

8M730-RAS-96-006

ATTACHMENT 1

Page 2 of 20

\subsection{INTRODUCTION}

Dose rate calculations have been made for $K$ Basin sludge contained inside a pipe as requested by the document in reference 1. Dose rates were calculated for a plastic pipe filled with sludge located underneath a water shield and for sludge inside a metal pipe. The pipe was assumed to have a length of 1000 $\mathrm{cm}$ to approximate an infinite pipe source term. Figure 1 shows a diagram of the different source and shielding configurations and the location of the dose points.

For the plastic pipe located under the water, the diameter of the source pipe was varied between $1,1.5$, and 2 inches. This pipe was then positioned at different depths within the water. The water depth was varied between 0.5 , $1.0,1.5,2.0,3.0$ feet. Above the water is a 4 foot air gap representing the region between the water and the floor grating. Dose rates were then calculated at $18 \mathrm{in}$. and $48 \mathrm{in}$. above the floor grate.

For the steel pipe, the diameter of the source pipe was varied between 1, 1.5, and 2 inches. The steel pipe was then varied between $2.375,3.5$, and 4.5 inches 0.D. with different pipe thicknesses analyzed for each pipe. For a. pipe with an $0 . D$. of 2.375 inches, the thickness of the pipe was $0.154,0.218$, 0.343 , or 0.436 inches. For a pipe with an 0.D. of 3.5 inches, the thickness of the pipe was $0.216,0.300,0.438$, or 0.600 inches. For a pipe with an 0.D. of 4,5 inches, the thickness of the pipe was $0.237,0.337,0.438,0.531$, or 0.674 inches. For each pipe analyzed, the dose rate was calculated at the surface and at 0.5 meters and 1 meter above the center of the pipe.

All dose rate calculations were made using the Isoshld-PC computer code (Reference 2).

\subsection{SUMMARY}

A dose rate of $0.5 \mathrm{mrem} / \mathrm{hr}$ is the target dose rate that must be achieved. For a plastic pipe under water, the dose rate will be less than or equal to 0.52 $\mathrm{mrem} / \mathrm{hr}(2.0 \mathrm{in}$. sludge source, $18 \mathrm{in}$. above the grate) when 3 feet of water is covering the pipe.

The dose rate for sludge in a metal pipe will be significantly greater than $0.5 \mathrm{mrem} / \mathrm{hr}$. The minimum surface dose rate is $753 \mathrm{mrem} / \mathrm{hr}$. The minimum dose rate at 0.5 meters is $648 \mathrm{mrem} / \mathrm{hr}$. The minimum dose rate at l meter is 50.1 $\mathrm{mrem} / \mathrm{hr}$.

To further reduce the dose rates for the metal pipes, additional lead shielding must be placed around the pipe. 7.5 to $10 \mathrm{~cm}$ of lead will be required to reduce the dose rate to less than $0.5 \mathrm{mrem} / \mathrm{hr}$ at 0.5 and 1 meter above the pipe.

\subsection{SOURCE}

The source for the sludge was obtained from Table 4.3 of Reference 3 . The source is the same as that used for the dose rate calculations reported in Reference 4. A density of $1.4 \mathrm{~g} / \mathrm{cc}$ was used for the sludge density. The water used as a shield for the results in Tables 1 and 2 is assumed to be nonradioactive. 
WHC-SD-SNF-DB-012, Rev. 0

8M730-RAS-96-006

ATTACHMENT 1

Page 3 of 20

\subsection{DOSE RATES FOR A PLASTIC PIPE UNDER WATER}

Table 1 summarizes the dose rates at $18 \mathrm{in}$. above the grate for the plastic pipe. Table 2 summarizes the dose rates at 48 in. above the grate for the plastic pipe. To keep the dose rate less than $0.5 \mathrm{mrem} / \mathrm{hr}$ at $18 \mathrm{in}$., the depth of water above the pipe must be at least $3.0 \mathrm{ft}$. Even with $3.0 \mathrm{ft}$. of water the dose rate is $0.521 \mathrm{mrem} / \mathrm{hr}$ for a source pipe with a diameter of 2.0 in.

Figure 2 shows a $70 g$ plot of the dose rates presented in Tabie 1 . The dose rate as a function of water thickness is linear on a $\log$ scale. As can be seen from this graph and the data from Tables 1 and 2, the dose rate is reduced by about a factor of 10 for every foot of water added as a shield above the pipe. Using this relationship, it is possible to determine the dose rate as a function of the depth of water for water depths not included in Tables 1 and 2 . The relationship between dose rate and water depth is given by the following equation.

$$
D_{2}=10^{\wedge}\left[\log \left(D_{1}\right)-0.97^{\star}\left(t_{2}-t_{1}\right)\right]
$$

where:

$D_{2}=$ The dose rate you want to determine $(\mathrm{mrem} / \mathrm{hr}$ ).

$D_{1}=$ The known dose rate (mrem/hr) from Table 1 or 2 .

$t_{1}=$ The water depth (ft.) for $D_{1}$.

$t_{2}=$ The water depth (ft.) for which you want the dose rate.

0.97 = Average constant derived from the slope of the lines in

Figure 2 . Actual values vary from 0.96 to 0.98 .

For example given that the dose rate for a 2.0 in sludge pipe inside under 1 $\mathrm{ft}$. of water is 52.7 at $18 \mathrm{in.}$ (Table 1 ), the above equation can be used to estimate the dose rate for a pipe under $3 \mathrm{ft}$. of water.

$$
10^{\wedge}[\log (52.7)-0.97 *(3-1)]=0.605
$$

This value compares well with the $0.521 \mathrm{mrem} / \mathrm{hr}$ value from Table 1 . The dose half thickness of water is about 0.31 feet.

Furthermore, since all of the lines shown in Figure 2 have approximately the same slope, the dose rate for different sludge pipe diameters differs by a single scaling factor. This scaling factor is approximately equal to the ratio of the cross sectional areas of the source pipe. In going from a 1.0 in. sludge pipe to a $1.5 \mathrm{in.} \mathrm{sludge} \mathrm{pipe} \mathrm{the} \mathrm{dose} \mathrm{rate} \mathrm{is} \mathrm{increased} \mathrm{by} \mathrm{a}$ factor of $2.2\left(.75^{\wedge} 2 / .5^{\wedge} 2=2.25\right)$. In going from a $1.0 \mathrm{in}$. sludge pipe to a 2.0 in. sludge pipe, the dose rate is increased by a factor of $3.9\left(1^{\wedge} 2 / .5^{\wedge} 2=4.0\right)$. This relationship also shows that the dose rates are roughly proportional to the source term (implying little self shielding in the sludge) so the dose rates are proportional to the amount of sludge in the pipe.

\subsection{DOSE RATES FOR A STEEL PIPE}

Table 3 lists the surface dose rates calculated for a steel pipe surrounding a sludge pipe. Three different steel pipes $(2.375,3.5,4.5$ in. 0.D.) were used with the three different source terms $(1.0,1.5,2.0 \mathrm{in.0.D.} \mathrm{s1udgo} \mathrm{pipe).}$ The values for a 2.0 in. sludge pipe with a 2.375 in. steel pipe are not 
WHC-SD-SNF-DB-012, Rev. 0

8M730-RAS-96-006

ATTACHMENT 1

Page 4 of 20

entered for a thickness of $.218, .343$, and $.436 \mathrm{in}$. because the inside diameter of these pipes is not large enough to hold a 2.0 in. sludge pipe.

Figure 3 shows a $\log$ plot of the surface dose rate as a function of steel thickness. This is a graphical representation of the information provided in Table 3 . The change in dose rate as a function of steel thickness is a straight line when displayed on a log plot.

Table 4 lists the dose rate at 0.5 meters above the center of the pipe. Figure 4 shows a $10 \mathrm{~g}$ plot of the dose rate at 0.5 meters above a metal pipe. This is a graphical representation of the information provided in Table 4 . Notice that the dose rate as a function of steel thickness for each source all lie on the same line. This was not true for the surface dose rate because the dose point is much closer to the source and the source geometry will affect the surface dose rate.

Table 5 lists the dose rate at 1 meter above the center of the pipe. Figure 5 shows a $\log$ plot of the dose rate at 1 meter above the steel pipe. This is a graphical representation of the information provided in Table 5 . Notice that the dose rate as a function of steel thickness for each source lie on the same line when plotted on a $\log$ scale.

Because the slope of the lines in Figures 3, 4, and 5 are the same, an equation can be developed that will predict the dose rate for an arbitrary steel thickness given a dose rate for a steel thickness that is include in Tables 3 through 5 :

$$
D_{2}=10^{\wedge}\left[\log \left(D_{1}\right)-0.45 *\left(t_{2}-t_{1}\right)\right]
$$

where:

$D_{2}=$ The dose rate you want to determine (mrem/hr)

$D_{1}=$ The known dose rate $(\mathrm{mrem} / \mathrm{hr}$ ) from Table 3,4 or 5 .

$t_{1}=$ The steel thickness (in.) for $D_{1}$.

$t_{2}=$ The steel thickness (in.) for which you want the dose rate.

$0.45=$ Average constant derived from the slope of the 7 ines in

Figures 3,4 and 5 . Actual values vary from 0.42 to 0.49 .

For example given that the dose rate for a 2.0 in sludge pipe inside a .216 in. thick steel pipe is 608 (Table 4), the above equation can be used to estimate the dose rate for a 0.6 in. thick pipe.

$$
10^{\wedge}\left[\log (608)-0.45^{*}(.6-.216)\right]=408
$$

This value compares well with the $399 \mathrm{mrem} / \mathrm{hr}$ value from Table 4 . The dose half thickness for steel is about 0.67 in.

\subsection{DOSE RATES FOR A STEEL PIPE WITH LEAD SHIELDING ADDED}

A1l of the dose rates presented in Table 3 through 5 are above the $0.5 \mathrm{mrem} / \mathrm{hr}$ desirable dose rate. To reduce these dose rates, a lead shield can be added to the steel pipe. Table 6 lists the amount of lead required to reduce the dose rate for each pipe to less than $0.5 \mathrm{mrem} / \mathrm{hr}$. The minimum steel thickness was used for each pipe since this will bound the other thicknesses. The lead 
shield was determined to the nearest 0.5 centimeters. Included in Table 6 is the dose rate calculated at 0.5 and 1 meter when the lead shield is in place. All of these values are equal to or less than $0.5 \mathrm{mrem} / \mathrm{hr}$. The dose half thickness of lead ia bout $1.2 \mathrm{~cm}$.

\subsection{DOSE RATE CALCULATIONS}

Table 7 summarizes all of the dose rate calculations made and includes the name of the input file and the Appendix that contains the input file.

\subsection{REFERENCES}

1. Memo, D. R. Precechtel to R. A. Schwarz, "Work Scope for the K Basin Wease 1

Pit Dose Rate Analysis," dated June 10, 1996.

2. P. D. Rittman, "ISO-PC Version 1.98 - User's Guide," WHC-SD-WM-UM-030, Rev. 0, 1995.

3. B. J. Makenas, editor, "Analysis of Sludge form Hanford K East Basin Floor and Weasel Pit," WHC-SP-1182, May 1996.

4. Memo, R. A. Schwarz to D. R. Precechtel, "Dose Rates in the K Basin Weasel Pit," 8M730-RAS-96-005, dated July 17, 1996. 
WHC-SD-SNF-DB-012, Rev. 0

8M730-RAS-96-006

ATTACHMENT 1

Page 6 of 20

Table 1. Dose Rates (mrem/hr) 18 in. Above the Grate for a Pipe Under Water

\begin{tabular}{|c|c|c|c||}
\hline \multirow{2}{*}{$\begin{array}{c}\text { Water depth } \\
(\mathrm{ft} .)\end{array}$} & \multicolumn{4}{|c||}{ Pipe Diameter } \\
\cline { 2 - 4 } & $1.0 \mathrm{in.}$ & $1.5 \mathrm{in.}$ & $2.0 \mathrm{in}$. \\
\hline 0.50 & $3.79 \mathrm{e}+01$ & $8.44 \mathrm{e}+01$ & $1.48 \mathrm{e}+02$ \\
\hline 1.00 & $1.35 \mathrm{e}+01$ & $3.00 \mathrm{e}+01$ & $5.27 \mathrm{e}+01$ \\
\hline 1.50 & $4.40 \mathrm{e}+00$ & $9.78 \mathrm{e}+00$ & $1.72 \mathrm{e}+01$ \\
\hline 2.00 & $1.39 \mathrm{e}+00$ & $3.08 \mathrm{e}+00$ & $5.42 \mathrm{e}+00$ \\
\hline 3.00 & $1.34 \mathrm{e}-01$ & $2.97 \mathrm{e}-01$ & $5.21 \mathrm{e}-01$ \\
\hline
\end{tabular}

Table 2. Dose Rates (mrem/hr) 48 in. Above the Grate for a Pipe Under Water

\begin{tabular}{|c|c|c|c|}
\hline \multirow{2}{*}{$\begin{array}{c}\text { Water depth } \\
(\mathrm{ft.} .)\end{array}$} & \multicolumn{3}{|c|}{ Pipe Diameter } \\
\cline { 2 - 4 } & $1.0 \mathrm{in.}$ & $1.5 \mathrm{in}$. & $2.0 \mathrm{in}$. \\
\hline 0.50 & $2.55 \mathrm{e}+01$ & $5.68 \mathrm{e}+01$ & $1.00 \mathrm{e}+02$ \\
\hline 1.00 & $9.55 \mathrm{e}+00$ & $2.13 \mathrm{e}+01$ & $3.74 \mathrm{e}+01$ \\
\hline 1.50 & $3.21 \mathrm{e}+00$ & $7.13 \mathrm{e}+00$ & $1.25 \mathrm{e}+01$ \\
\hline 2.00 & $1.03 \mathrm{e}+00$ & $2.29 \mathrm{e}+00$ & $4.03 \mathrm{e}+00$ \\
\hline 3.00 & $1.03 \mathrm{e}-01$ & $2.28 \mathrm{e}-01$ & $4.00 \mathrm{e}-01$ \\
\hline
\end{tabular}


WHC-SD-SNF-DB-012, Rev. 0

8M730-RAS-96-006

ATTACHMENT 1

Page 7 of 20

Table 3. Surface Dose Rates (mrem/hr) for a Metal Pipe.

\begin{tabular}{|c|c|c|c|}
\hline \multirow{2}{*}{ Shield Pipe Dimensions } & \multicolumn{3}{|c|}{ Sludge Pipe Diameter } \\
\hline & $1.0 \mathrm{in.}$ & $1.5 \mathrm{in}$. & $2.0 \mathrm{in.}$ \\
\hline 2.375 in. 0.D., 0.154 in. thick & $2.23 e+03$ & $4.88 \mathrm{e}+03$ & $8.51 \mathrm{e}+03$ \\
\hline 2.735 in. $0.0 ., 0.218$ in. thick & $2.09 e+03$ & $4.56 e+03$ & $--\cdots-$ \\
\hline 2.375 in. $0.0 ., 0.343$ in. thick & $1.83 e+03$ & $3.98 \mathrm{e}+03$ & ----- \\
\hline 2.375 in. $0.0 ., 0.436$ in. thick & $1.65 \mathrm{e}+03$ & $3.58 \mathrm{e}+03$ & ----- \\
\hline 3.5 in. $0.0 ., 0.216$ in. thick & $1.54 \mathrm{e}+03$ & $3.33 e+03$ & $5.73 e+03$ \\
\hline 3.5 in. 0.0., 0.300 in. thick & $1.41 \mathrm{e}+03$ & $3.05 e+03$ & $5.22 \mathrm{e}+03$ \\
\hline 3.5 in. $0.0 ., 0.438$ in. thick & $1.21 \mathrm{e}+03$ & $2.62 e+03$ & $4.47 \mathrm{e}+03$ \\
\hline 3.5 in. 0. D., 0.600 in. thick & $1.01 \mathrm{e}+03$ & $2.18 \mathrm{e}+03$ & $3.71 \mathrm{e}+03$ \\
\hline 4.5 in. 0.D., 0.237 in. thick & $1.22 e+03$ & $2.63 e+03$ & $4.51 e+03$ \\
\hline 4.5 in. 0.D., 0.337 in. thick & $1.10 e+03$ & $2.36 \mathrm{e}+03$ & $4.04 \mathrm{e}+03$ \\
\hline 4.5 in. 0. D., 0.438 in. thick & $9.81 e+02$ & $2.11 e+03$ & $3.61 \mathrm{e}+03$ \\
\hline 4.5 in. $0.0 ., 0.531$ in. thick & $8.85 e+02$ & $1.91 \mathrm{e}+03$ & $3.24 \mathrm{e}+03$ \\
\hline 4.5 in. 0. D., 0.674 in thick & $7.53 e+02$ & $1.62 \mathrm{e}+03$ & $2.75 \mathrm{e}+03$ \\
\hline
\end{tabular}


WHC-SD-SNF-DB-012, Rev. 0

8M730-RAS-96-006

ATTACHMENT 1

Page 8 of 20

Table 4. Dose Rates (mrem/hr) at 0.5 Meters above a Metal Pipe.

\begin{tabular}{|c|c|c|c|}
\hline \multirow{2}{*}{ Shield Pipe Dimensions } & \multicolumn{3}{|c|}{ Sludge Pipe Diameter } \\
\hline & $1.0 \mathrm{in.}$ & $1.5 \mathrm{in.}$ & $2.0 \mathrm{in.}$ \\
\hline 2.375 in. 0. D., 0.154 in. thick & $1.76 \mathrm{e}+02$ & $3.80 \mathrm{e}+02$ & $6.48 \mathrm{e}+02$ \\
\hline 2.375 in. 0. D., 0.218 in. thick & $1.66 \mathrm{e}+02$ & $3.57 \mathrm{e}+02$ & ---- \\
\hline $2.375 \mathrm{in}, 0.0 ., 0.343 \mathrm{in}$. thick & $1.45 \mathrm{e}+02$ & $3.12 \mathrm{e}+02$ & ----- \\
\hline 2.375 in. 0.D., 0.436 in. thick & $1.31 \mathrm{e}+02$ & $2.82 e+02$ & $---\cdot-$ \\
\hline 3.5 in. 0. D., 0.216 in. thick & $1.66 \mathrm{e}+02$ & $3.57 e+02$ & $6.08 \mathrm{e}+02$ \\
\hline 3.5 in. 0. D., 0.300 in. thick & $1.52 \mathrm{e}+02$ & $3.27 e+02$ & $5.56 \mathrm{e}+02$ \\
\hline 3.5 in. 0.D., 0.438 in. thick & $1.31 \mathrm{e}+02$ & $2.82 \mathrm{e}+02$ & $4.79 \mathrm{e}+02$ \\
\hline 3.5 in. 0.D., 0.600 in. thick & $1.10 \mathrm{e}+02$ & $2.35 \mathrm{e}+02$ & $3.99 \mathrm{e}+02$ \\
\hline 4.5 in. $0.0 ., 0.237$ in. thick & $1.62 \mathrm{e}+02$ & $3.50 \mathrm{e}+02$ & $5.95 e+02$ \\
\hline 4.5 in. $0.0 ., 0.337$ in. thick & $1.46 \mathrm{e}+02$ & $3.14 e+02$ & $5.35 e+02$ \\
\hline 4.5 in. $0.0 ., 0.438$ in. thick & $1.31 \mathrm{e}+02$ & $2.82 \mathrm{e}+02$ & $4.79 \mathrm{e}+02$ \\
\hline 4.5 in. $0.0 ., 0.531$ in. thick & $1.18 \mathrm{e}+02$ & $2.54 \mathrm{e}+02$ & $4.31 e+02$ \\
\hline 4.5 in. 0.D., 0.674 in. thick & $1.01 \mathrm{e}+02$ & $2.16 \mathrm{e}+02$ & $3.67 \mathrm{e}+02$ \\
\hline
\end{tabular}


WHC-SD-SNF-DB-012, Rev. 0

8M730-RAS-96-006

ATTACHMENT 1

Page 9 of 20

Table 5. Dose Rates (mrem/hr) at 1 Meter above a Metal Pipe.

\begin{tabular}{|c|c|c|c|}
\hline \multirow{2}{*}{ Shield Pipe Dimensions } & \multicolumn{3}{|c|}{ Sludge Pipe Diameter } \\
\hline & $1.0 \mathrm{in.}$ & $1.5 \mathrm{in.}$ & $2.0 \mathrm{in.}$ \\
\hline 2.375 in. $0.0 ., 0.154$ in. thick & $8.55 e+01$ & $1.85 \mathrm{e}+02$ & $3.17 \mathrm{e}+02$ \\
\hline 2.375 in. O.D., 0.218 in. thick & $8.09 e+01$ & $1.75 \mathrm{e}+02$ & $---\cdots$ \\
\hline 2.375 in. $0.0 ., 0.343$ in. thick & $7.17 \mathrm{e}+01$ & $1.55 \mathrm{e}+02$ & ---- \\
\hline 2.375 in. O.D., 0.436 in. thick & $6.51 \mathrm{e}+01$ & $1.40 \mathrm{e}+02$ & ---- \\
\hline 3.5 in. 0.D., 0.216 in. thick & $8.11 \mathrm{e}+01$ & $1.75 \mathrm{e}+02$ & $2.99 \mathrm{e}+02$ \\
\hline 3.5 in. $0.0 ., 0.300$ in. thick & $7.49 e+01$ & $1.61 \mathrm{e}+02$ & $2.75 \mathrm{e}+02$ \\
\hline 3.5 in. $0.0 ., 0.438$ in. thick & $6.50 e+01$ & $1.40 \mathrm{e}+02$ & $2.37 e+02$ \\
\hline $3.5 \mathrm{in} .0 . \mathrm{D},, 0.600 \mathrm{in}$. thick & $5.45 e+01$ & $1.17 \mathrm{e}+02$ & $1.98 \mathrm{e}+02$ \\
\hline 4.5 in. 0.D., 0.237 in. thick & $7.95 e+01$ & $1.72 \mathrm{e}+02$ & $2.93 e+02$ \\
\hline 4.5 in. 0. D., 0.337 in. thick & $7.22 \mathrm{e}+01$ & $1.55 \mathrm{e}+02$ & $2.65 e+02$ \\
\hline $4.5 \mathrm{in.} 0 . \mathrm{D}, \mathrm{,} 0.438 \mathrm{in}$. thick & $6.50 \mathrm{e}+01$ & $1.40 \mathrm{e}+02$ & $2.37 e+02$ \\
\hline 4.5 in. 0.0., 0.531 in. thick & $5.88 \mathrm{e}+01$ & $1.26 e+02$ & $2.14 \mathrm{e}+02$ \\
\hline 4.5 in. $0.0 ., 0.674$ in. thick & $5.01 \mathrm{e}+01$ & $1.08 \mathrm{e}+02$ & $1.82 \mathrm{e}+02$ \\
\hline
\end{tabular}


WHC-SD-SNF-DB-012, Rev. 0

8M730-RAS-96-006

ATTACHMENT 1

Page 10 of 20

Table 6. Lead Thickness required to Reduce Dose Rate to Less than $0.5 \mathrm{mrem} / \mathrm{hr}$

\begin{tabular}{|c|c|c|c|c|}
\hline \multirow[t]{2}{*}{ Shield Pipe Dimensions } & \multicolumn{2}{|c|}{0.5 meters } & \multicolumn{2}{|c|}{1 meter } \\
\hline & $\begin{array}{l}\text { Lead thick } \\
(\mathrm{cm})\end{array}$ & $\begin{array}{l}\text { dose rate } \\
(\mathrm{mrem} / \mathrm{hr})\end{array}$ & $\begin{array}{c}\text { Lead thick } \\
(\mathrm{cm})\end{array}$ & $\begin{array}{l}\text { dose rate } \\
\text { (mrem } / \mathrm{hr} \text { ) }\end{array}$ \\
\hline $\begin{array}{l}2.375 \text { in. o.0., } 0.154 \text { in. thick, } 1.0 \\
\text { in. } 0.0 \text {. Sludge pipe }\end{array}$ & 8.50 & 0.37 & 7.50 & 0.42 \\
\hline $\begin{array}{l}2.375 \text { in. O.D., } 0.154 \text { in. thick, } 1.5 \\
\text { in. 0.0. Sludge Pipe }\end{array}$ & 9.50 & 0.34 & 8.50 & 0.39 \\
\hline $\begin{array}{l}2.375 \text { in. O.D., } 0.154 \text { in. thick, } 2.0 \\
\text { in. } 0.0 \text {. Sludge Pipe }\end{array}$ & 10.00 & 0.38 & 9.00 & 0.44 \\
\hline $\begin{array}{l}3.5 \text { in. 0.D., } 0.216 \text { in. thick, } 1.0 \\
\text { in. 0.0. Sludge Pipe }\end{array}$ & 8.50 & 0.34 & 7.50 & 0.39 \\
\hline $\begin{array}{l}3.5 \text { in. } 0.0 ., 0.216 \text { in. thick, } 1.5 \\
\text { in. } 0.0 \text {. Sludge Pipe }\end{array}$ & 9.00 & 0.48 & 8.50 & 0.36 \\
\hline $\begin{array}{l}3.5 \text { in. O.D., } 0.216 \text { in. thick, } 2.0 \\
\text { in. 0.D. Sludge Pipe }\end{array}$ & 10.00 & 0.35 & 9.00 & 0.40 \\
\hline $\begin{array}{l}4.5 \text { in. 0.D., } 0.237 \text { in. thick, } 1.0 \\
\text { in. 0.0. Sludge Pipe }\end{array}$ & 8.00 & 0.50 & 7.50 & 0.38 \\
\hline $\begin{array}{l}4.5 \text { in. } 0.0 ., 0.237 \text { in. thick, } 1.5 \\
\text { in. 0.0. Sludge Pipe. }\end{array}$ & 9.00 & 0.47 & 8.50 & 0.35 \\
\hline $\begin{array}{l}4.5 \text { in. } 0.0 .0 .237 \text { in. thick, } 2.0 \\
\text { in. O.D. Sludge Pipe }\end{array}$ & 10.00 & 0.34 & 9.00 & 0.39 \\
\hline
\end{tabular}

Table 7. Isoshld-PC Input Files.

\begin{tabular}{|l|l|l|}
\hline File Name & Description & Appendix \\
\hline \hline pipes1dg.in & $\begin{array}{l}\text { Dose rates for a plastic pipe under water. Inner } \\
\text { sludge pipe diameter of } 1.0,1.5, \text { and } 2.0 \text { in., } \\
\text { water depth of } 0.5,1.0,1.5,2.0, \text { and } 3.0 \mathrm{ft} .\end{array}$ & $\mathrm{A}$ \\
\hline meta1.in & $\begin{array}{l}\text { Dose rates from a metal pipe. Inner sludge pipe } \\
\text { diameter of } 1.0,1.5, \text { and } 2.0 \text { in., metal pipe 0.D. } \\
\text { of } 2.375,3.5, \text { and } 4.5 \text { in. }\end{array}$ & B \\
\hline lead1.in & $\begin{array}{l}\text { Dose rates } 1.0 \text { meter from a metal pipe with a 1ead } \\
\text { shield added. Inner sludge pipe diameter of } 1.0, \\
1.5, \text { and } 2.0 \text { in., steel pipe 0.D. of } 2.375 \text { in., } \\
0.154 \text { in. thick, lead thickness varied from } 7.5 \mathrm{~cm} \\
\text { to } 10 \text { cm to reduce dose rate to less than } 0.5 \\
\text { mrem/hr. }\end{array}$ & $\mathrm{C}$ \\
\hline leadhalf.in & $\begin{array}{l}\text { Same as leadhalf.in for dose rates at } 1.0 \text { meters } \\
\text { above the center of the metal pipe. }\end{array}$ & $\mathrm{D}$ \\
\hline
\end{tabular}




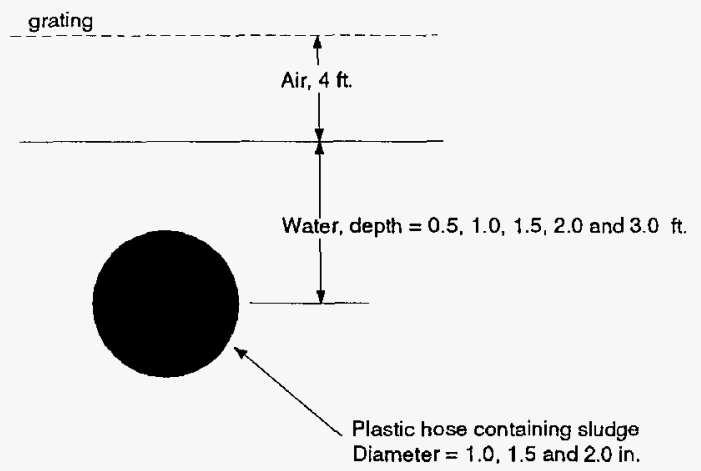

Dose rate at 1.5 meters

- Dose rate at 0.5 meters

2.375 in. O.D., .154, .218, .343 and .436 thick 3.5 in. O.D., .216, $300, .438$ and .600 thick

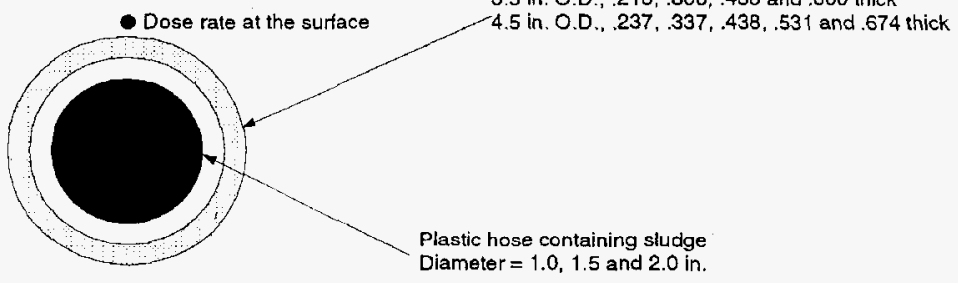


WHC-SD-SNF-DB-012, Rev. 0

8M730-RAS-96-006

ATTACHMENT 1

Page 12 of 20

Figure 2. Dose Rates (mrem/hr) for a Pipe Under Water

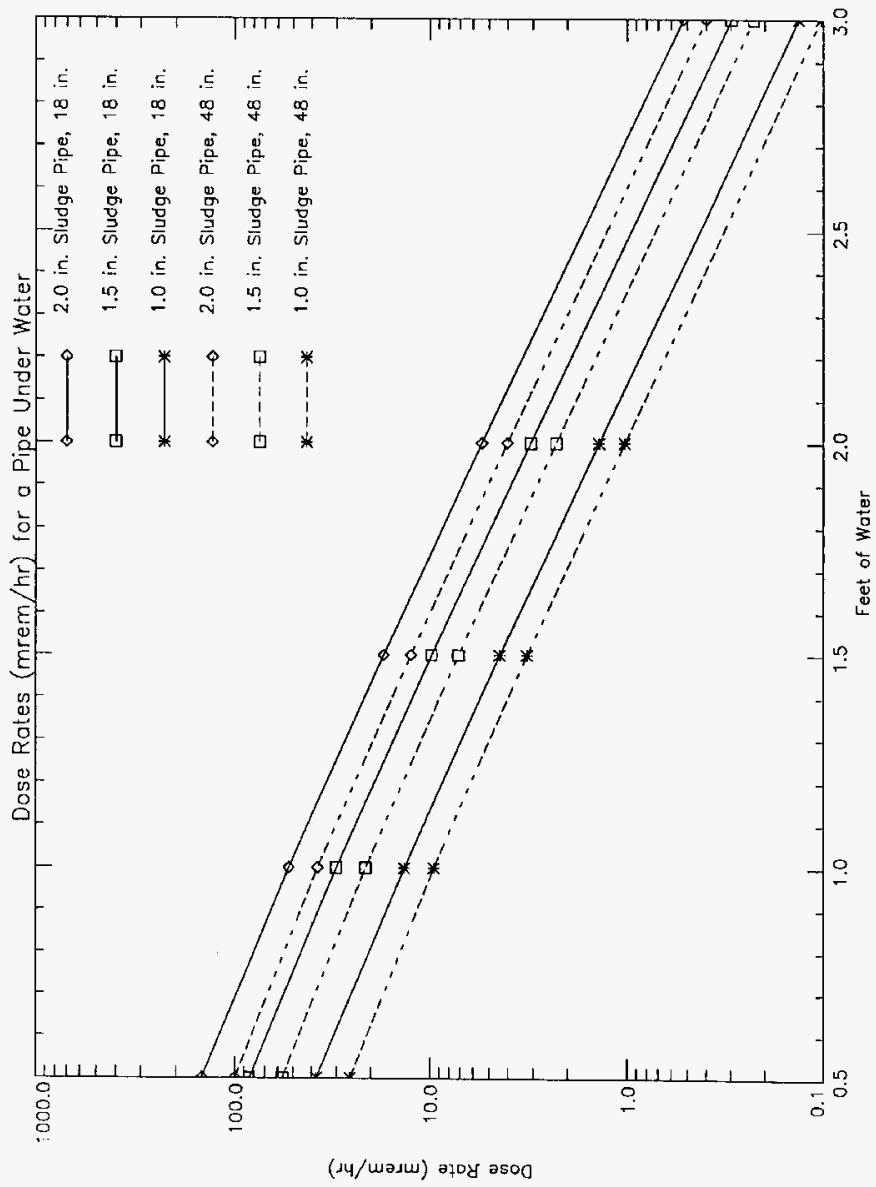


WHC-SD-SNF-DB-012, Rev. 0

8M730-RAS-96-006

ATTACHMENT 1

Page 13 of 20

Figure 3. Surface Dose Rates (mrme/hr) for a Steel Pipe.

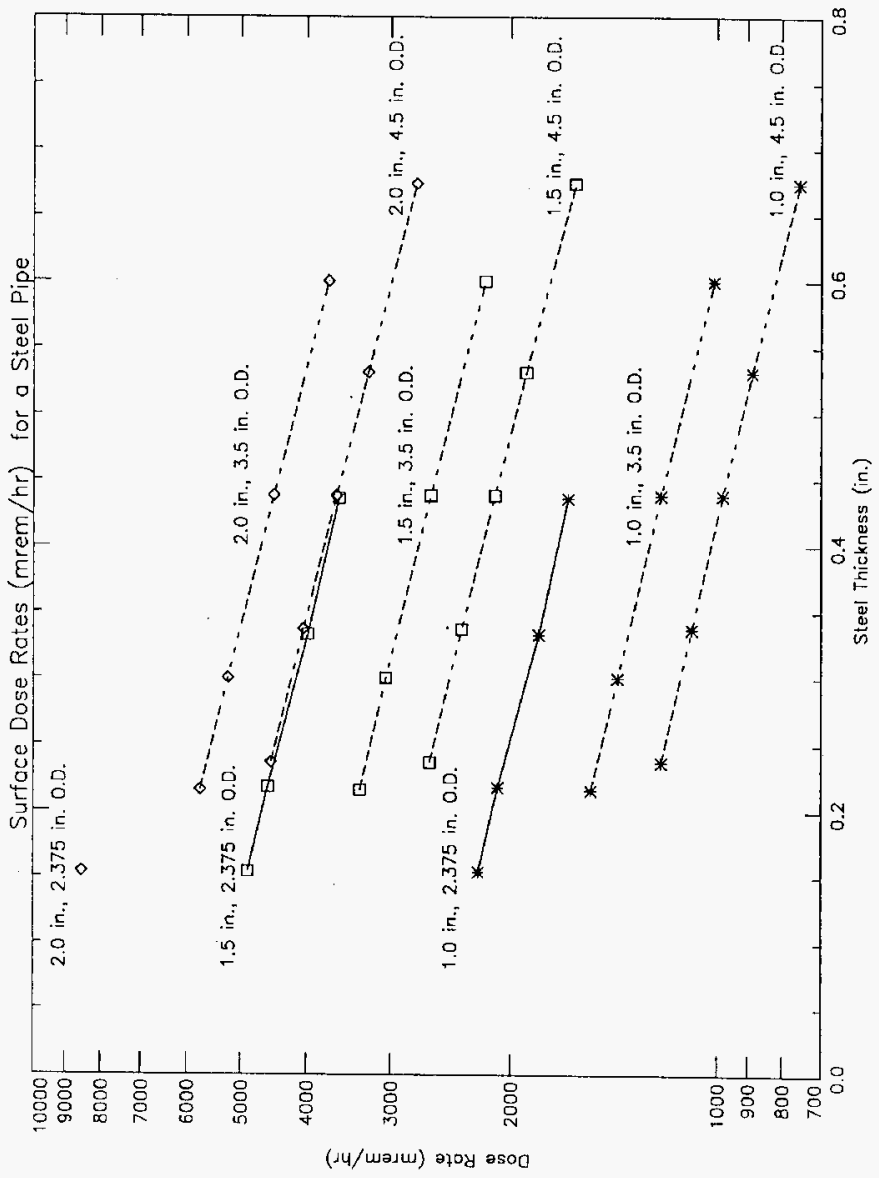


WHC-SD-SNF-DB-012, Rev. 0

8M730-RAS-96-006

ATTACHMENT 1

Page 14 of 20

Figure 4. Dose Rates (mrem/hr) at 0.5 Meters from a Steel Pipe.

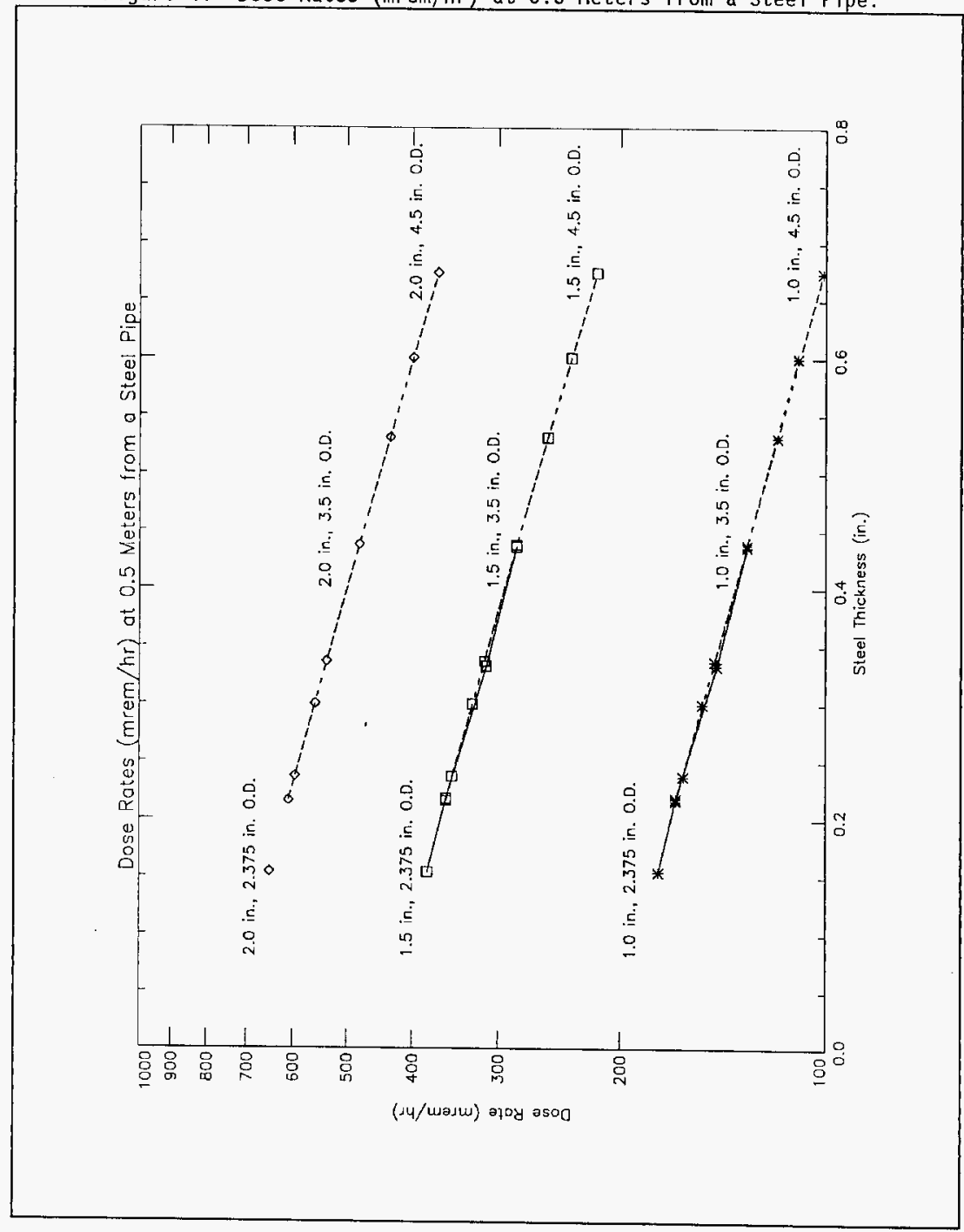


WHC-SD-SNF-DB-012, Rev. 0

8M730-RAS-96-006

ATTACHMENT 1

Page 15 of 20

Figure 5. Dose Rates (mrem/hr) at 1.0 Meters from a Steel Pipe.

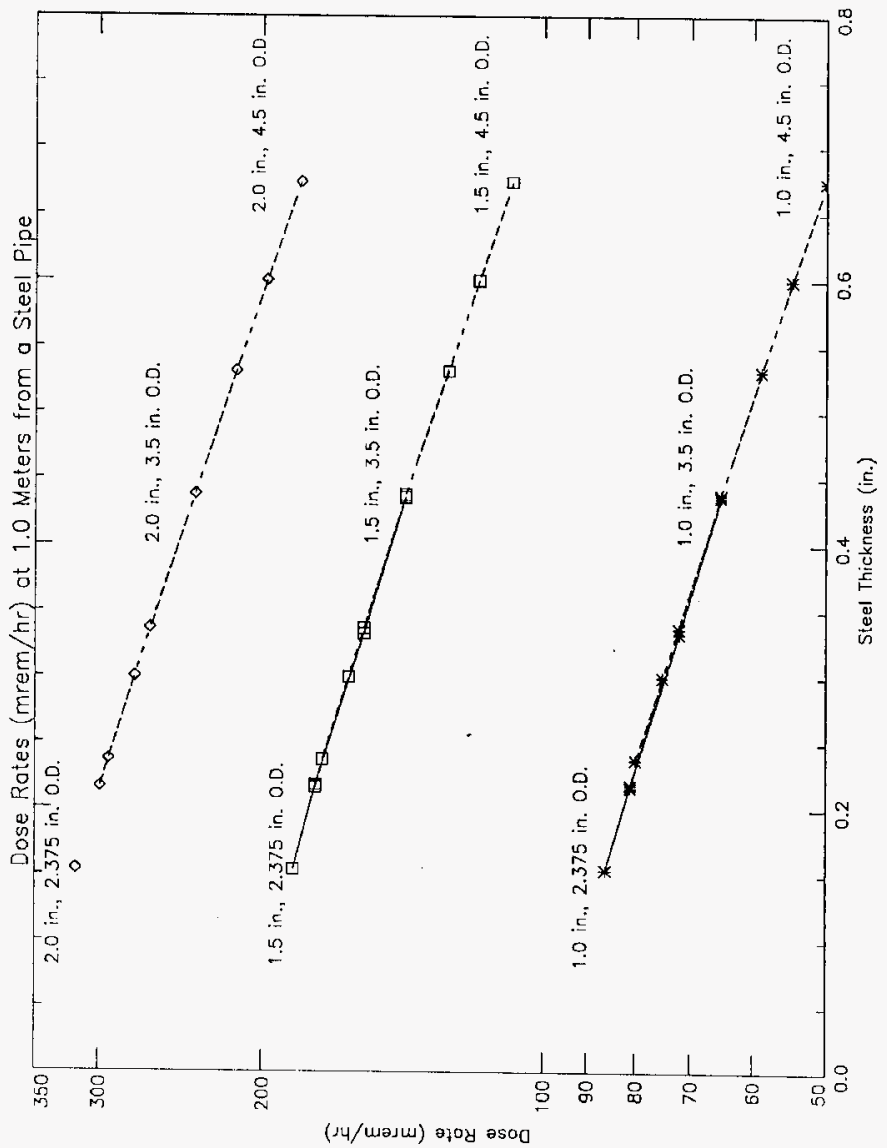




\section{Appendix A. ISOSHLD-PC Input File pipesldg.in}

0

1.0 in. pipe, $0.5 \mathrm{ft}$. of water

\&Input Next $=1$, Option $=1$, Dunit $=1$, I conc $=1$, I geom $=8, \quad s(t)=1000, Y=500$,

Npsi=100, N theta $=100$, Del $r=0.1, X(1)=182.88,259.08$,

Nshld $=2$, Jbuf $=2, T(1)=1.27, T(2)=13.97$

We ight $(472)=.943$,

Weight $(335)=211$, weight $(336)=211$,

Weight $(319)=0.461$,

Weight $(415)=1.59$

Weight (418) $=0.719$,

Weight $(376)=5.897$, weight $(377)=5.897$,

Weight $(111)=0.231$,

Weight $(170)=8.614$, Weight $(172)=8.614$,

Weight $(485)=11.3$,

Weight $(525)=1.81$,

Weight $(408)=0.358$,

Weight $(269)=1.89$

Weight $(496)=8.98$,

Weight $(493)=8.88$, Weight $(494)=8.88$,

Weight $(492)=0.862$,

Weight $(502)=0.00141$,

Weight $(506)=6.46$, Weight $(500)=6.46$,

Weight $(82)=179$, Weight $(84)=179$,

Weight $(519)=2.03 e-2$,

Weight $(520)=2.44 \mathrm{e}-2$,

Weight $(476)=7.91 \mathrm{e}-4$

Weight (526) $=1.73 \mathrm{e}-2$ \&

1 water $11.4 \quad 1.0$

$1.5 \mathrm{in}$. pipe, $0.5 \mathrm{ft}$. of water

\&Input Next $=4, T(1)=1.905, T(2)=13.335$ \&

$2.0 \mathrm{in}$. pipe, $0.5 \mathrm{ft}$. of water

\&Input Next $=4, T(1)=2.54, T(2)=12.7$ \&

$1.0 \mathrm{in}$. pipe, $1.0 \mathrm{ft}$. of water

\&I nput Next $=4, T(1)=1.27, T(2)=29.21, x(1)=198.12,274.32$ \&

$1.5 \mathrm{in}$. pipe, $1.0 \mathrm{ft}$. of water

\&Input Next $=4$, $T(1)=1.905, T(2)=28.575$

$2.0 \mathrm{in}$. pipe, $1.0 \mathrm{ft}$. Of water

\&Input Next $=4, T(1)=2.54, T(2)=27.94$ \&

1.0 in. pipe, $1.5 \mathrm{ft}$. of water

\&Input Next $=4, \mathrm{~T}(1)=1.27, T(2)=44.45, X(1)=213.36,289.56 \&$

$1.5 \mathrm{in}$. pipe, $1.5 \mathrm{ft}$. of water

\&Input Next $=4, T(1)=1.905, T(2)=43.815 \quad$ \&

$2.0 \mathrm{in}$. pipe, $1.5 \mathrm{ft}$. of water

\&Input Next $=4, \quad \mathrm{~T}(1)=2.54, \mathrm{~T}(2)=43.18 \&$

$1.0 \mathrm{in}$. pipe, $2.0 \mathrm{ft}$. of water

8I Input Next $=4, T(1)=1.27, T(2)=59.69, X(1)=228.6,304.8$ \&

$1.5 \mathrm{in}$. pipe, $2.0 \mathrm{ft}$. of water

8Input Next $=4, T(1)=1.905, T(2)=59.055$ \&

$2.0 \mathrm{in}$. pipe, $2.0 \mathrm{ft}$. of water

\&Input Next $=4, T(1)=2.54, T(2)=58.42 \&$

$1.0 \mathrm{in}$. pipe, $3.0 \mathrm{ft}$. of water

\& Input Next $=4$, $T(1)=1.27, T(2)=90.17, X(1)=259.08,335.28 \quad$ \&

1.5 in. pipe, $3.0 \mathrm{ft}$. of water

\&[nput Next $=4, T(1)=1.905, T(2)=89.535$ \&

$2.0 \mathrm{in}$. pipe, $3.0 \mathrm{ft}$. of water

\&Input Next $=4, T(1)=2.54, T(2)=88.9 \quad$ \&

END OF RUN

\&Input Next $=6$ \& 
Appendix B. ISOSHLD-PC Input File metal.in

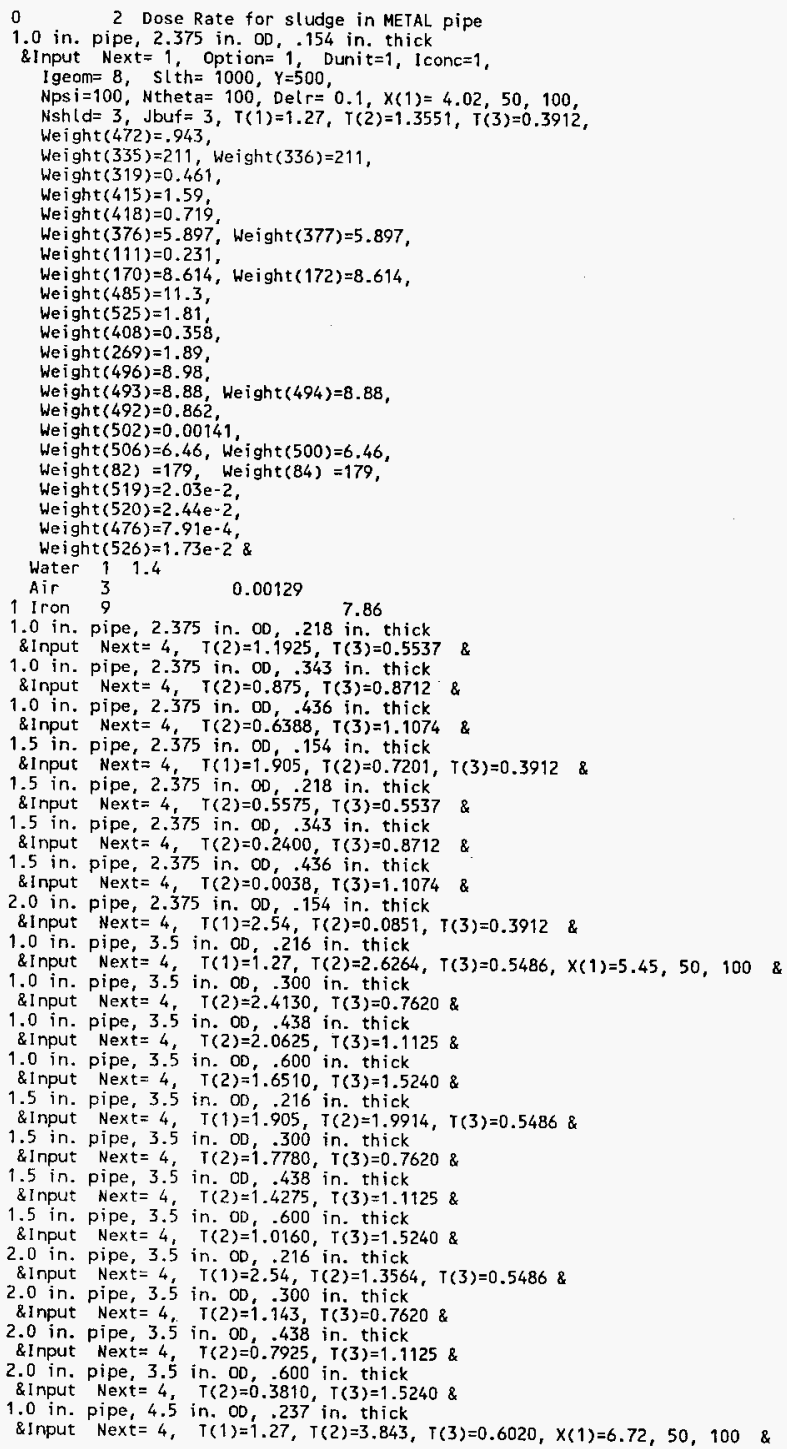




\section{WHC-SD-SNF-DB-012, Rev. 0}

8M730-RAS-96-006

ATTACHMENT 1

Page 18 of 20

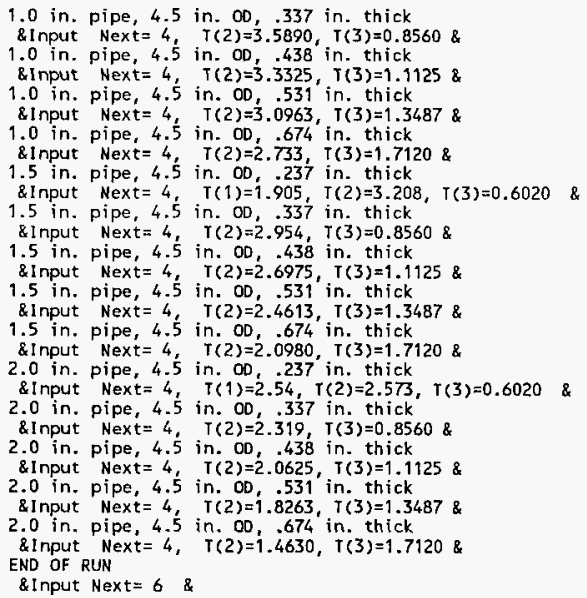


WHC-SD-SNF-DB-012, Rev. 0

8M730-RAS-96-006

ATTACHMENT 1

Page 19 of 20

\section{Appendix C. ISOSHLD-PC Input File leadl.in}

0

$1.0 \mathrm{in.}$ pipe, $2.375 \mathrm{in} .00, .154 \mathrm{in}$. thick, $7.5 \mathrm{~cm}$ of lead

\&Input Next $=1$, option $=0$, Dunit $=1$, I conc $=1$,

Igeom $=8$, sith $=1000, Y=500$,

Nps $i=100$, Ntheta $=100$, Del $r=1, X(1)=100$,

Nshld $=4$, Jbuf $=4, T(1)=1.27, T(2)=1.3551, T(3)=0.3912, T(4)=7.5$, Weight $(472)=.943$,

Weight $(335)=211$, Weight $(336)=211$

Weight $(319)=0.461$.

Weight $(415)=1.59$

Weight $(418)=0.719$

We ight $(376)=5.897$, Weight $(377)=5.897$,

Weight $(111)=0.231$,

Weight $(170)=8.614$, Weight $(172)=8.614$

Weight $(485)=11.3$,

Weight $(525)=1.81$

Weight $(408)=0.358$,

Weight $(269)=1.89$,

We ight $(496)=8.98$

Weight $(493)=8.88$, Weight $(494)=8.88$,

We ight $(492)=0.862$,

Weight $(502)=0.00141$

Weight $(506)=6.46$, Weight $(500)=6.46$,

Weight $(82)=179$, Weight $(84)=179$,

Weight $(519)=2.03 \mathrm{e}-2$

Weight $(520)=2.44 \mathrm{e}-2$,

Weight $(476)=7.91 \mathrm{e}-4$;

Weight $(526)=1.73 \mathrm{e}-2$ \&

Water 11.4

Air 3

0.00129

1 Lead 14

7.86

14 Lead 14.35

1.5 in. pipe, 2.375 in. OD, $.154 \mathrm{in.}$ thick, $8.5 \mathrm{~cm}$ of lead

8Input Next $=4, T(1)=1.905, T(2)=0.7201, T(3)=0.3912, T(4)=8.5$ \&

$2.0 \mathrm{in.}$ pipe, $2.375 \mathrm{in.} \mathrm{OD,} .154 \mathrm{in.} \mathrm{thick,} 9.0 \mathrm{~cm}$ of lead

\&. Input Next $=4, T(1)=2.54, T(2)=0.0851, T(3)=0.3912, T(4)=9.0$ \&

$1.0 \mathrm{in.}$ pipe, $3.5 \mathrm{in}$. OD, $216 \mathrm{in}$. thick, $7.5 \mathrm{~cm}$ of lead

\&Input Next $=4, T(1)=1.27, T(2)=2.6264, I(3)=0.5486, T(4)=7.5$ \&

$1.5 \mathrm{in}$. pipe, $3.5 \mathrm{in} .00, .216$ in. thick, $8.5 \mathrm{~cm}$ of lead

\&Input Next $=4, T(1)=1.905, T(2)=1.9914, T(3)=0.5486, T(4)=8.5$ \&

$2.0 \mathrm{in.}$ pipe, $3.5 \mathrm{in}$. $00, .216$ in. thick, $9.0 \mathrm{~cm}$ of lead

\&. Input Next $=4, T(1)=2.54, T(2)=1.3564, T(3)=0.5486, T(4)=9.0$ \&

1.0 in. pipe, 4.5 in. $00, .237$ in. thick, $7.5 \mathrm{~cm}$ of lead

\&Input Next $=4, T(1)=1.27, T(2)=3.843, T(3)=0.6020, T(4)=7.5$ \&

1.5 in. pipe, $4.5 \mathrm{in.} 00, .237 \mathrm{in.} \mathrm{thick,} 8.5 \mathrm{~cm}$ of lead

\&. Input Next $=4, T(1)=1.905, T(2)=3.208, T(3)=0.6020, T(4)=8.5 \&$

$2.0 \mathrm{in}$. pipe, $4.5 \mathrm{in}$. $00, .237 \mathrm{in}$. thick, $9.0 \mathrm{~cm}$ of lead

\& Input Next $=4, T(1)=2.54, T(2)=2.573, T(3)=0.6020, T(4)=9.0 \quad$ \&

END OF RUN

\&. Input Next $=6$ \& 
WHC-SD-SNF-DB-012, Rev, 0

8M730-RAS-96-006

ATTACHMENT 1

Page 20 of 20

Appendix D. ISOSHLD-PC Input File leadhalf.in

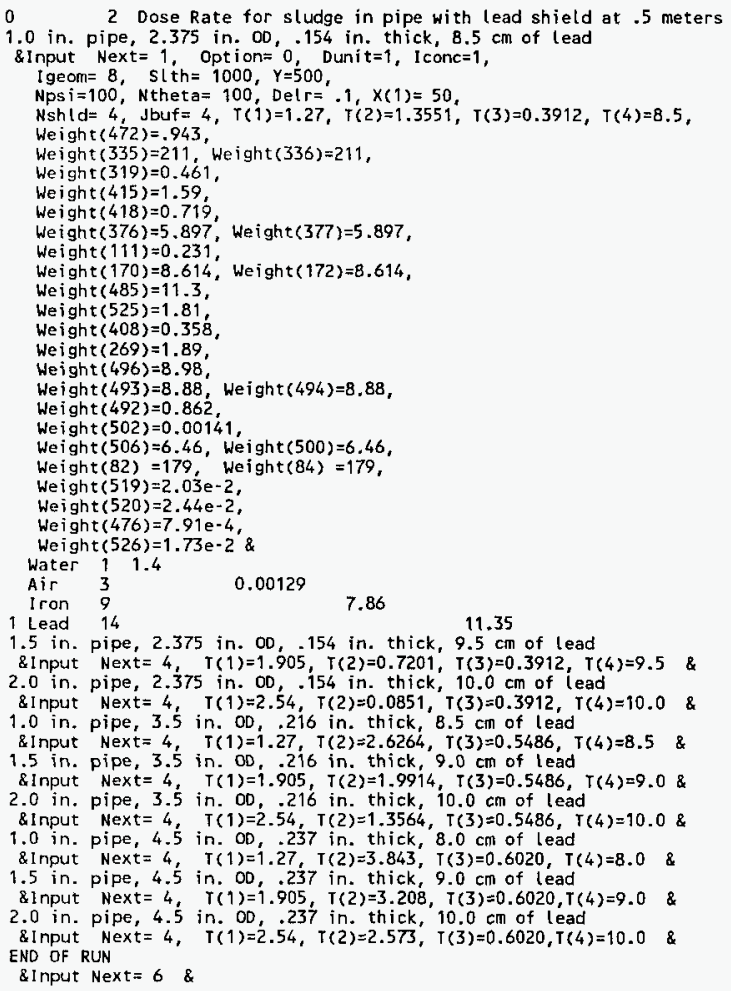


CHECKLIST FOR INDEPENDENT TECHNICAL REVIEW

NUMBER: $8 M 730-$ RAS-96-006

DOCUMENT REVIEWED Dose Rates for Sludge in a Pipe

\section{AUTHOR(s) R. A. Schwarz}

I. Method(s) of Review

$(\checkmark)$ Input data checked for accuracy

( ) Hand calculation

( $\checkmark$ ) Alternate computer code: MCNP POINT KERNAL, MICROSHIELD

( ) Comparison to experiment or previous results

( ) Alternate method (define)

II. Check1 ist (either check or enter $\overline{N A}$ if not applied)

$(\checkmark)$ Task completely defined

( - Activity consistent with task specification

( $)$ Necessary assumptions explicitly stated and supported

( $\checkmark)$ Resources properly identified and referenced

$(\checkmark)$ Resource documentation appropriate for this application

$(\checkmark)$ Input data explicitly stated

$(\checkmark)$ Input data verified to be consistent with original source

( $\checkmark$ ) Geometric model adequate representation of actual geometry

$(\checkmark)$ Material properties appropriate and reasonable

() Mathematical derivations checked including dimensional consistency

( ) Hand calculations checked for errors

$(\checkmark)$ Assumptions explicitly stated and justified

$(\checkmark)$ Computer software appropriate for task and used within range of validity

( ) Use of resource outside range of established validity is justified

$(\checkmark)$ Software runstreams correct and consistent with results

( $v$ ) Software output consistent with input

() Resuits consistent with applicable previous experimental or analytical findings

$(\checkmark)$ Results and conclusions address all points and are.consistent with task requirements and/or established limits or criteria

$(\checkmark)$ Conclusions consistent with analytical results and established limits

( ) Uncertainty assesment appropriate and reasonable

( ) other (define)

III. Comments:

IV. REVIEWER: $\sqrt{\text { ictor Roetman }}$ DATE: 31 July 1996 
WHC-SD-SNF-DB-012, Rev. 0

APPENDIX D

GAS EVOLUTION IN WEASEL PIT

S. A. Brisbin 
WHC-SD-SNF-DB-012, Rev. 0

Westinghouse

Internali-

Hanford Company

Memo

From: Engineering Support

$S A B-96-002$

Phone: $\quad 376-9180$ R3-48

Date: June 13, 1996

Subject: EVALUATION OF GAS RETENTION IN $105 \mathrm{~K}$ EAST BASIN WEASEL PIT SLUDGE

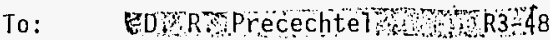

$\begin{array}{ll}\text { cc: C. J. Alderman } & \text { R3-48 } \\ \text { W. B. Barton } & \mathrm{R} 2-11 \\ \text { K. H. Bergsman } & \mathrm{R} 3-48 \\ \text { S. D. Estey } & \mathrm{R} 2-11 \\ \text { M. D. Guthrie } & \mathrm{R} 1-43 \\ \text { G. S. Hunacek } & \text { X3-79 } \\ \text { L. M. McWethy } & \mathrm{R} 3-48 \\ \text { F. J. Muller } & X 3-85 \\ \text { R. J. Nicklas } & \mathrm{R} 1-43 \\ \text { D. L. Sherre11 } & \mathrm{R} 3-85 \\ \text { K Basins Project } & \\ \text { File } & \text { X3-85 } \\ \text { SNF Project File } & \mathrm{R} 3-11 \\ \text { SAB File/LB } & \end{array}$

Reference: WHC-SD-WM-TI-755, "An Analysis of Parameters Describing Gas Retention/Release Behavior in Double She11 Tank Waste," Revision 0, dated 1996.

A question was raised regarding the potential for flammable gas (i.e. hydrogen) to. be retained within the sludge stored in the $105 \mathrm{~K}$ East Basin Weasel Pit. Based upon the information provided in the reference, there does not appear to be a potential for unacceptable retention of gas within the $105 \mathrm{~K}$ East Basin Weasel Pit.

Tank Waste Remediation System (TWRS) Waste Tank Process Engineering performed an investigation to determine if new or additional control limits could be imposed to prevent adverse accumulations of gas within double-shell tank (DST) waste. The results of the investigation revealed that there is a clear link between the propensity of DST waste to retain gas and the depth of the waste classified as non-convective. The investigation also found that the best correlation of tank waste properties and the degree to which waste may retain and episodically release gas was determined by the product of the total solids (non-convective waste) volume and the specific gravity of the liquid (convective waste) in contact with the solids. The results, to date, show that no episodic gas releases have been observed in DSTs where the product of the total solids depth in inches multiplied by the specific gravity of the contacting liquid is less that 150 . Conversely, for the six DSTs known to experience episodic gas releases, this product was always found to exceed 230 . The results of that investigation are documented in the reference. 
D. R. Precechtel

Page 2

June 13, 1996

Assuming that the referenced relationship applies to $105 \mathrm{~K}$ East Basin siudge and that the specific gravity of the contacting liquid is approximately 1.1, GRE behavior is indicated to be unlikely as long as the maximum depth of the solids does not exceed 136 inches (1l feet). Conversely, GRE behavior is indicated to be likely if the solids depth exceeds 209 inches (17 feet).

\section{.. $150=1.1 \times$ maximum depth in inches Maximum depth in inches $=136$ \\ $230=1.1 \times$ solids depth in inches \\ Solids depth in inches $=209$}

Current calculations indicate that the sludge depth in the Weasel pit will not exceed 8.5 feet. Therefore, sludge storage in the Weasel Pit should not present a safety issue due to GRE behavior. Assuming that siudge will always be covered by at least 4 feet of water while stored in the basin and the basin water depth will not exceed 17.5 feet, it is not functionally possible to reach the solids depth where GRE behavior is likely.

If you have questions or comments regarding this memo, please contact me at $376-9180$.

\section{Sa Briabin}

S. A. Brisbin, Advanced Engineer

Engineering Support

$\operatorname{tn}$

CONCURRENCE
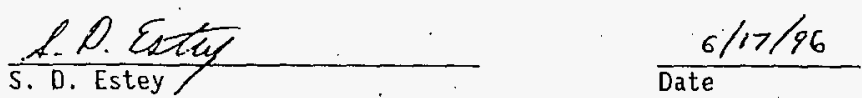
WHC-SD-SNF-DB-012, Rev. 0

APPENDIX E

SLUDGE VOLUME MANAGEMENT

D. R. Precechtel

E-1 
WHC-SD-SNF-DB-012, Rev. 0

K BASIN SLUDGE MANAGENENT

\subsection{OBJECTIVES}

1.1 Determine the volume of sludge that can be stored in the Wease1

Pit and also the volume using both the Weasel Pit and the Weasel

Pit Channe1.

1.2 Establish a sludge retrieval sequence and time phase.

1.3 Estimate the KE Basin sludge transfer rate to TWRS.

1.4 Create a time dependent chart for Weasel Pit sludge volume projections.

\subsection{ASSUMPTIONS}

2.1 Sludge volumes as shown in Table 2.1, page 2.10, of WHC-SD-SNF-TI015 , Rev. 0 . Segregation Pit Discharge Chute siudge has already been pumped to Weasel Pit.

2.2 Weasel Pit used for interim storage of all sludge. Two cases are as sumed:

a. Sludge is stored only in the Weasel Pit, with a volume of $56.1 \mathrm{~m} 3$ (17 feet) deep.

b. Sludge is stored in the Weasel Pit and the Weasel Pit channel with a volume of $79.1 \mathrm{~m} 3$ (17 feet) deep.

2.3 Assume the allowable sludge depth is half the water depth (16 feet nominal, 17 feet water level increased for dose reduction).

\section{Sludge Storage Volumes, $\mathrm{m} 3$}

Depth

8.0 feet

8.5 feet
Weasel Pit

26.4

28.05

Weasel Pit and Channel

37.2

39.53

\subsection{REFERENCE CASE}

Sludge management for the reference case assumes retrieval of floor sludge after fuel removal is complete and after rack removal. Sludge is removed after all fuel, debris, and non-permanent structures are first removed. The sludge is removed just after rack removal is completed in each bay. The sludge volumes in the Weasel Pit are calculated and shown in Attachment 1 , assuming a 28 month removal campaign.

\subsection{JUST-IN-TIME}


WHC-SD-SNF-DB-012, Rev. 0

Pre-cleaning the main bays before fuel movement could reduce turbidity and water born dose sources significantly during fuel removal. The basin would be given a final cleaning after fuel and rack removal. This Just-InTime option was analyzed for both the nominal and the maximum expected sludge volumes. These results are shown in Attachments 2 and 3 , both assuming as 12 month sludge removal campaign in the year 2000 .

\subsection{CONCLUSIONS}

With the limitation on sludge depth being $3.3 \mathrm{~m}$ (11 feet), it is seen that both the Weasel Pit and channel are needed to assure having enough storage capacity for sludge for this just-in-time option. The performance of the Weasel Pit to function as a settling basin with $3.3 \mathrm{~m}$ (11 feet) of sludge must be confirmed to validate this option. 
WHC-SD-SNF-DB-012, Rev. 0

ATTACHMENT 1

KE BASIN SLUDGE MANAGEMENT, REFERENCE CASE

D.R. Precechtel 


\section{DESIGN CALCULATION}

(1) Drawing

(2) Doc No.

(3) Page 11 of 29

(4) Building

(5) Rev.

(6) Job No.

(7) Subject

KE Basin Sludge Management

(8) Originator D. R. Precechtel

Q.R. freveltif

(9) Checker L. M. Mchethy zrinirexti;

Date $2 / 26 / 96$

Date $2 / 27 / 96$

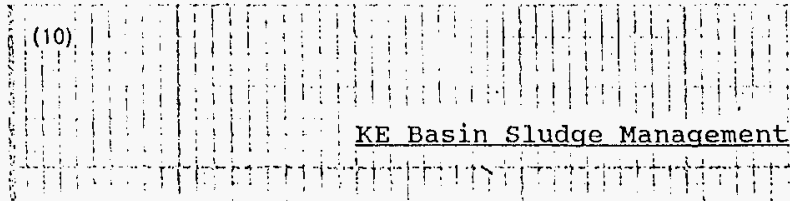

Calculations of sludge volume management for KE Basin

1. Sludge? volumes as ishown in Table 2.1 , page 2.10 , of

i WHC-SD-SNF-TI-015, Rev, 0 . Segregation'pit sludge has 1 1! already been pumped to weasel pit (seelpage 8) 2 Weasel pit used for interim storage of all siudge to Two

a. siudge is stored only in the weasel pit twith a volume of $52.8 \mathrm{~m}^{3}$ (16 feet deep) 1 w.

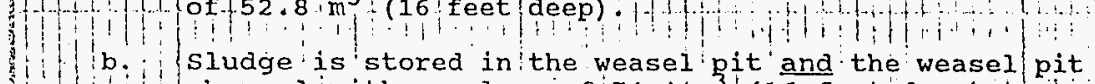
( 1 channel with a volume of $74.4 \mathrm{~m}^{3}$ (16. feet deep)

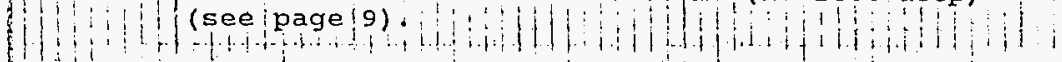

3. Assume the allowable sludge depth is half the wateri depth

- (16 feet nominal;!17 feet after water/level increased, for;

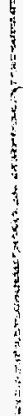

\section{sludge storage volumes $\mathrm{m}^{3}$ \\ sludge}

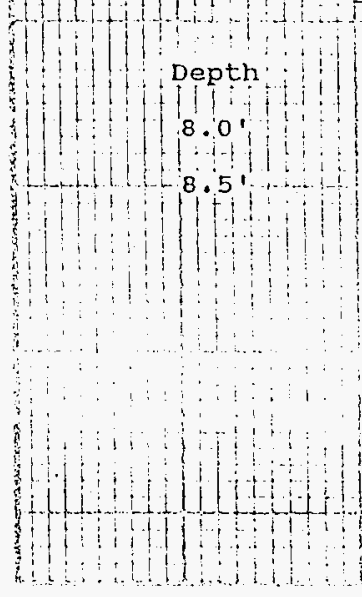

Weasel pit

Weasel pit and channel

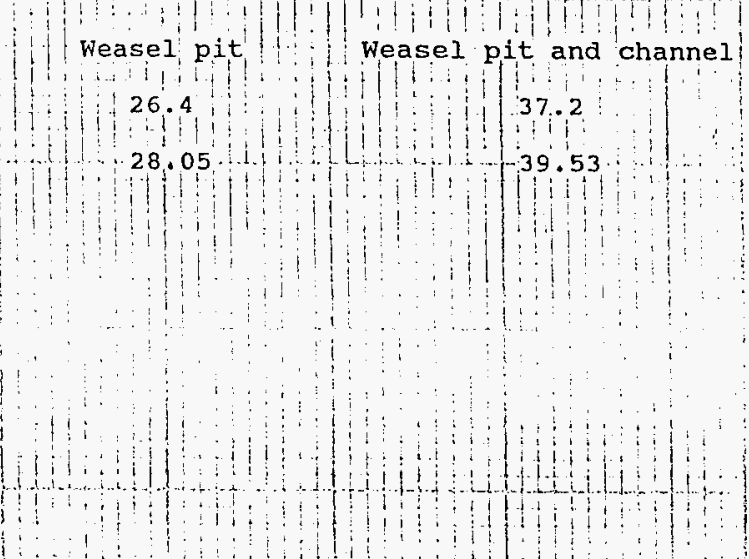




\section{DESIGN CALCULATION}

(1) Drawing (2) Doc. No.

(3) Page _ 2 of 29

(4) Building (5) Rev. (6) Job No.

(7) Subject KE Rasia Sludge_Management

(B) Originator $D$. R. Precechtel

(9) Checker L. M. McHethy

Date $\frac{2 / 26 / 96}{2 / 27 / 96}$

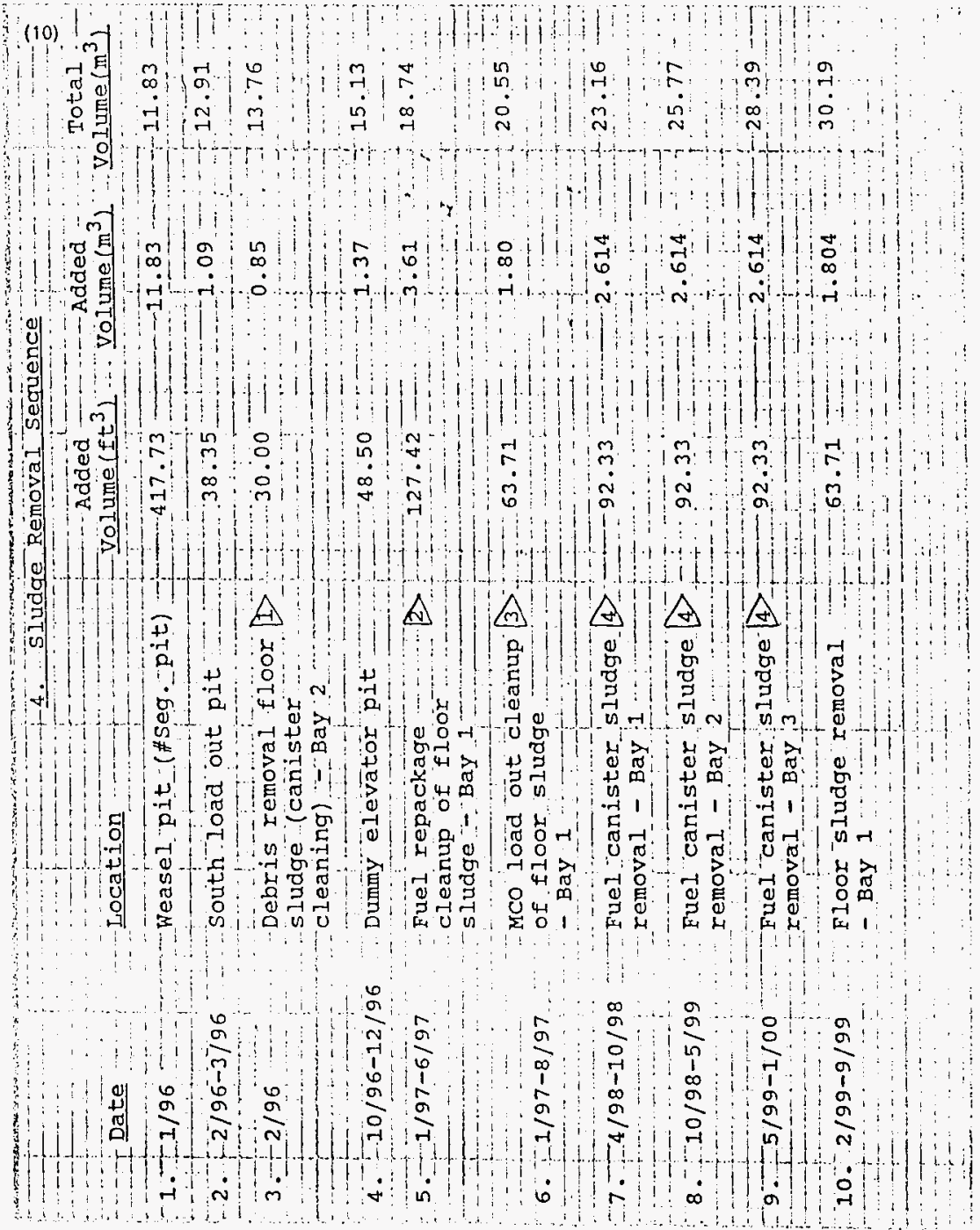




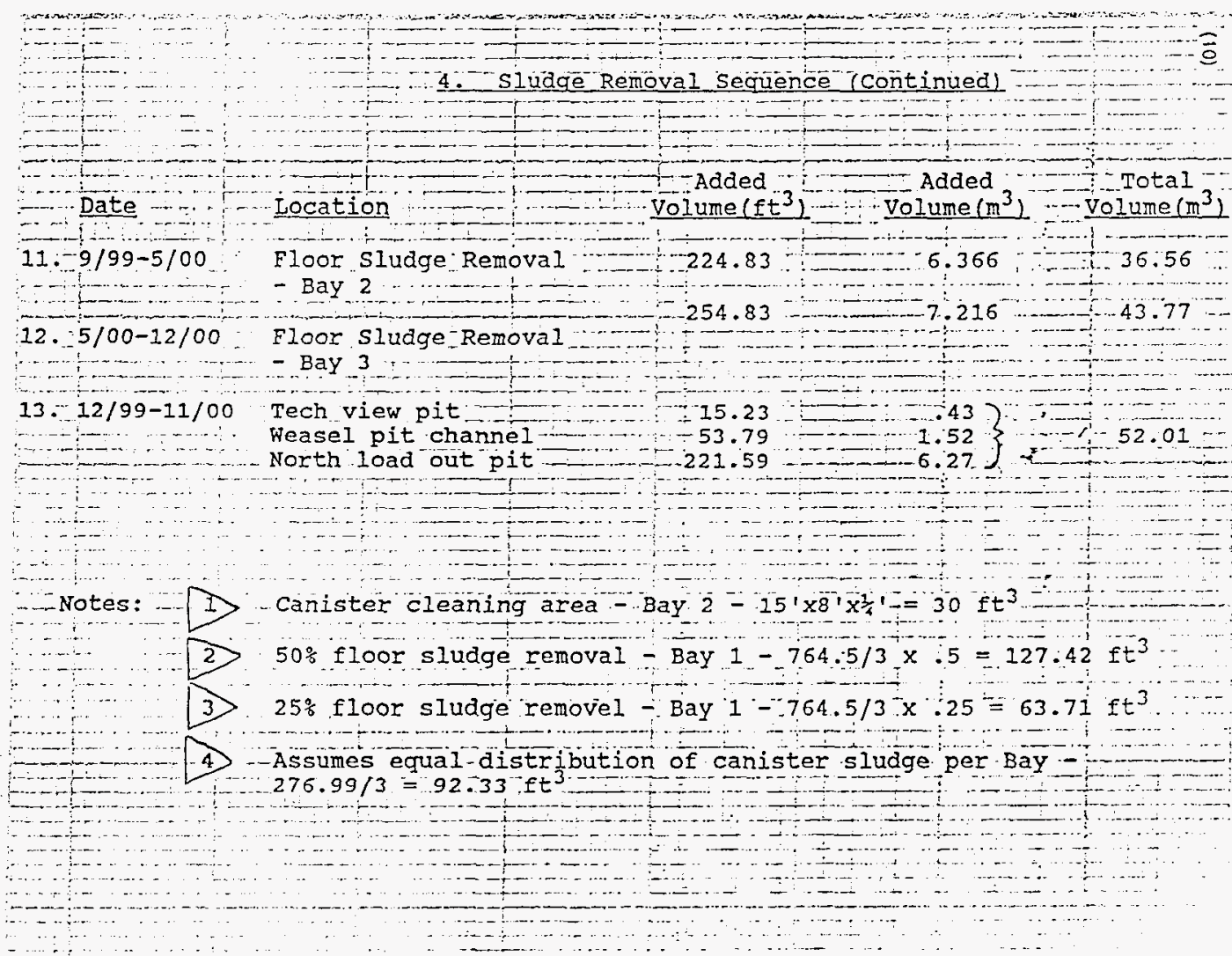

Ð $\doteq \equiv \equiv$

을ํํㄷำ 
(1) Drawing

(4) Building

(7) Subject

(8) Originato

(9) Checker L. M. McWethy
(2) Doc. No.

(5) Rev.

(6) Job No

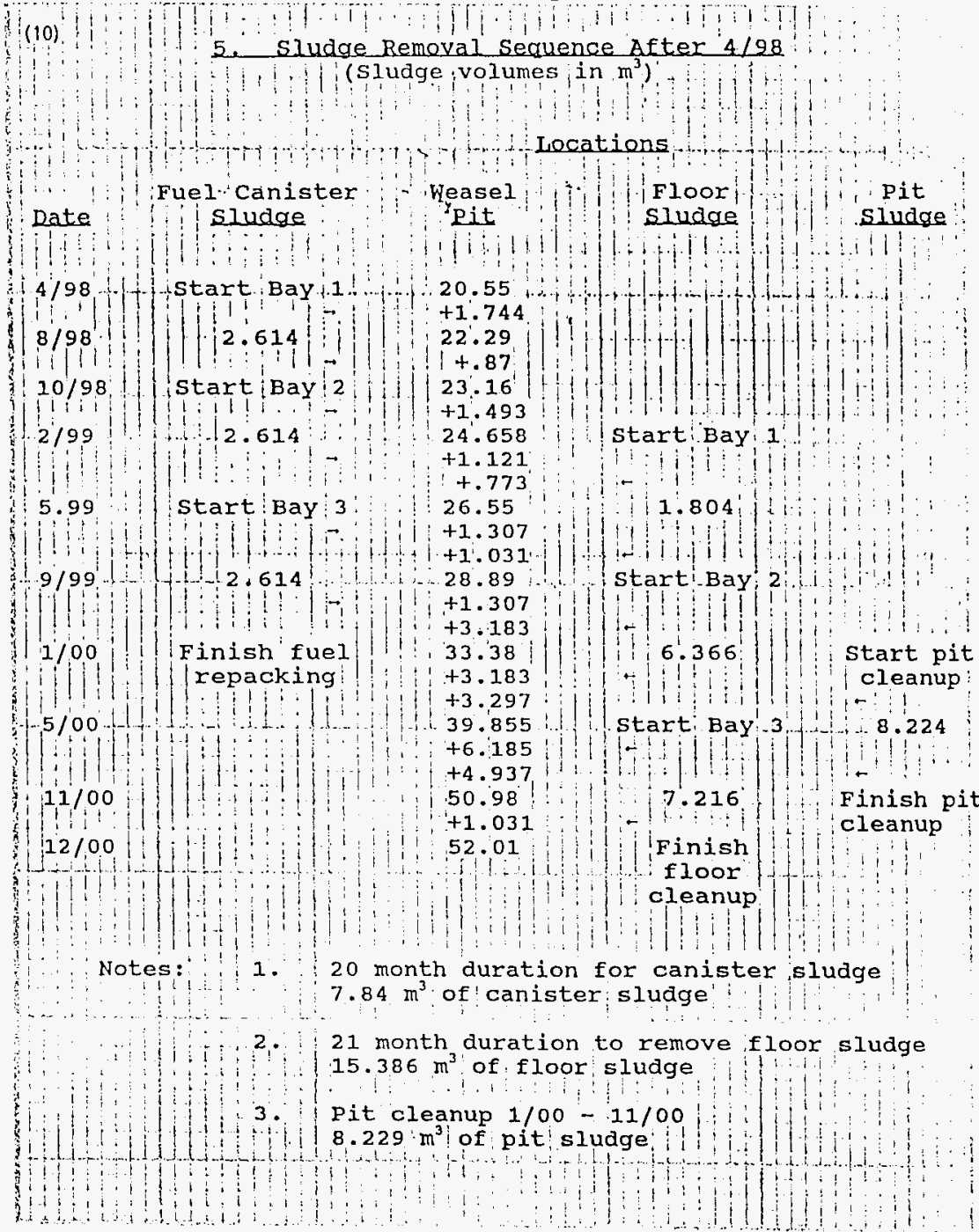




\section{DISIGN CALCULATION}

(1) Drawing

(2) Doc. No.

(3) Page 5 of 9

(4) Building

(5) Rev

(6) Job No

(7) Subject

KE Basin Siudge Maragement

(8) Originator D. R. Precechtel

(9) Checker L.M. Mchlethy

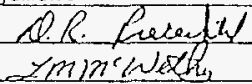

Date

$2 / 26 / 96$ Date

$z / 22 / 36$

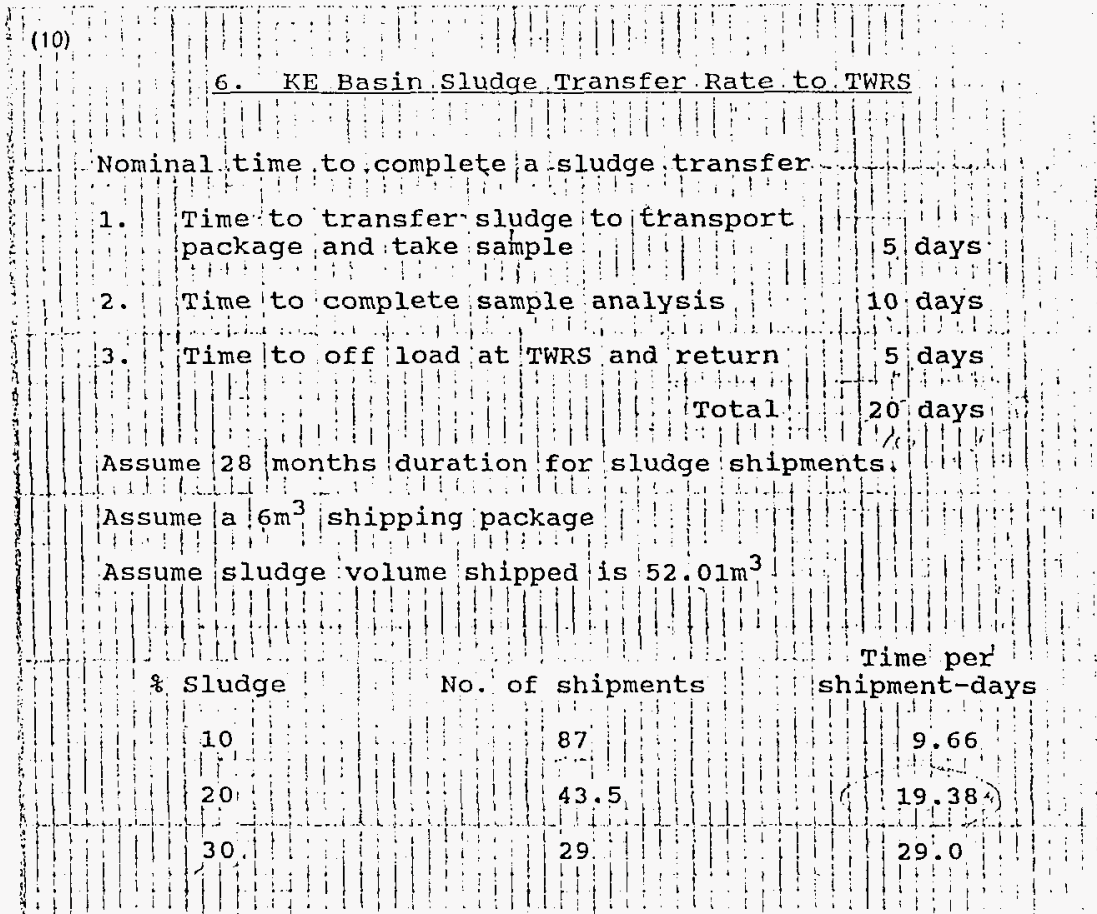

Conclude a sludge percentage of $20 \%$ in needed to accomplish sludge shipments 'with 'a single transport package. Two transports are being 'procured to allow for all uncertainties.

Nominal shipping Rate: $52.01 / 28=1.8575 \mathrm{~m}^{3} / \mathrm{month}$
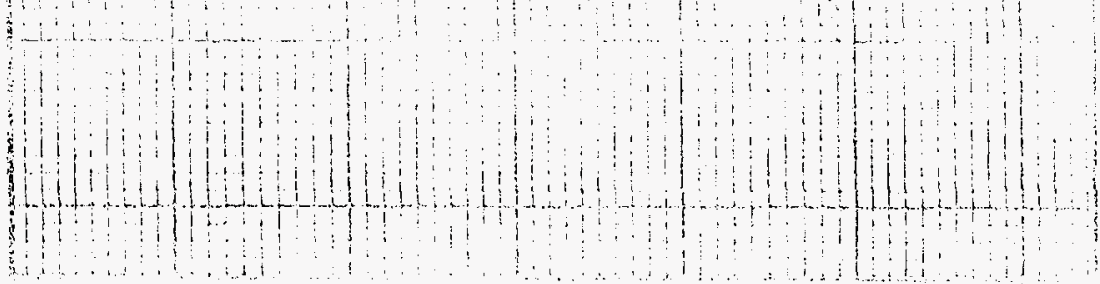


\section{DESIGN CALCULATION}

(1) Drawing

(2) Doc. No

(4) Building

(5) Rey

(3) Page 6 of 9

(7) Subject KE Basin Sludge ldanagement

(8) Originator D. R. Precechtel (1) K Eusechtel Date $2 / 26 / 96$

(9) Checker L. M. McWethy

Date

$2 / 27 / 92$

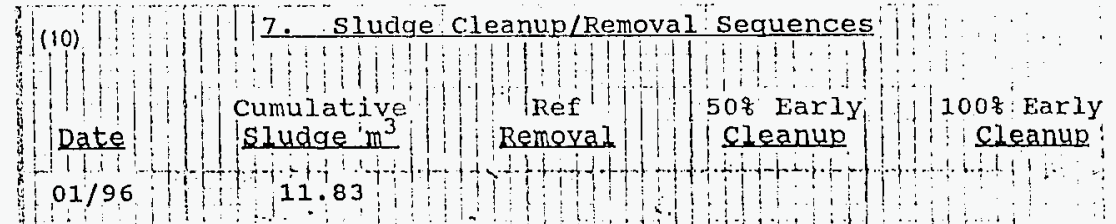

$02 / 96 \quad 12.68$

$03 / 96$

$10 / 96$

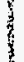

$12 / 96$

$11 \mid 111$

i

1

$06 / 97 \quad 18.74$

$08 / 97 \quad \square \quad 20.55$

10/97 $\quad \begin{aligned} & 20.55 \\ & 1\end{aligned}$

1.11911)

13.

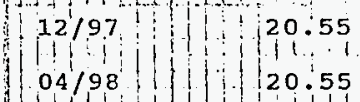

1

$\begin{array}{r}11 \\ 08 / 98\end{array} \mid \begin{aligned} & 1 \\ & 1 \\ & 1 \\ & 22 \\ & 1\end{aligned}$

$10 / 98$

22.29

$\left\{\begin{array}{r}02 / 99^{\circ} \\ 24.66\end{array}\right.$

i.

$05 / 99 \quad 26.55$

$09 / 99$
$1 / 1+128.89$

$01 / 00 \quad \begin{aligned} & 3 \\ & 33.38\end{aligned}$
0

$05 / 00$

39.86

$11 / 00$

50.98

1.11
19.45

13
132

9.84

4.75

28.24

35.94

$17+17$

$12 / 00$
1
1

1.81

1
28.24
11
29.98
1
1.14
30.85
1

:

35.94

37,68

38.55

40.04

32.35

41.16

33.85

42.47

35.68

43.78

0.85

38.58

47.07

0.83

51.49

52.01

0.00

52.01

52.01 


\section{DESIGN CALCULATION}

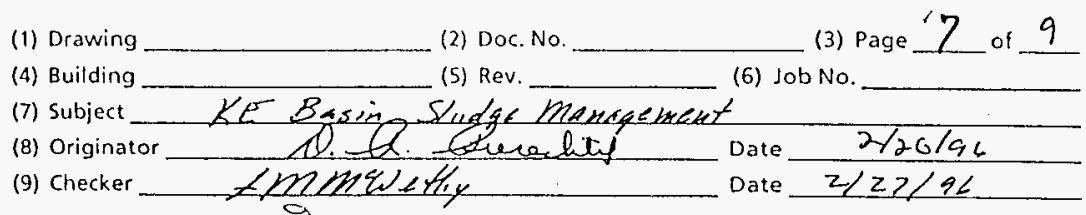

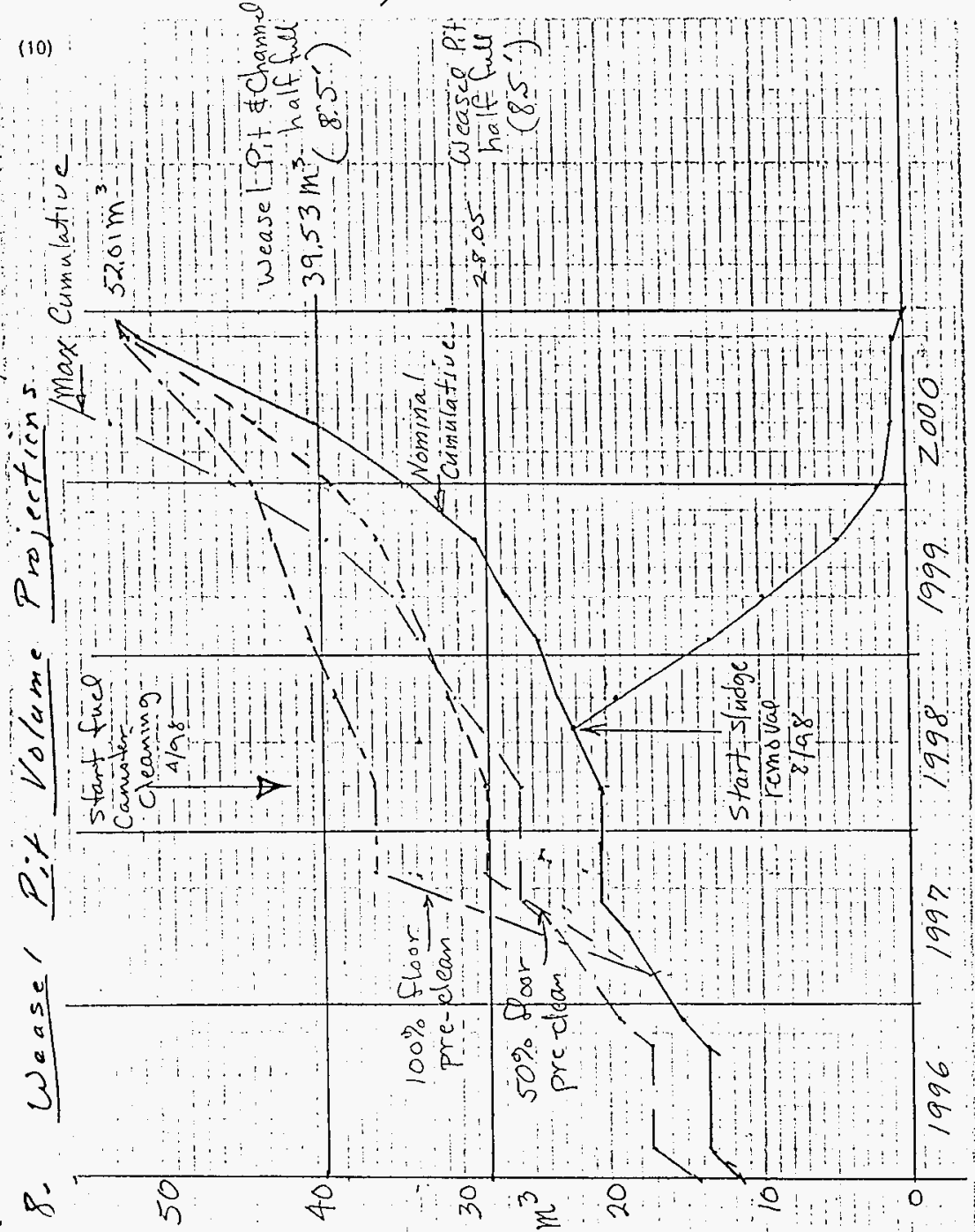


WHC-SO-SNF-TI-015, Rev. 0

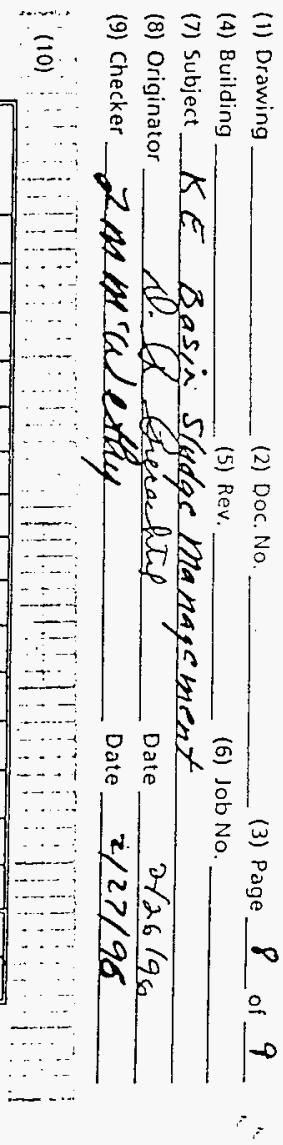

Table 2.1. Sludge Volumes of $K$ East Basin and Estimated Uncertainties

\begin{tabular}{|c|c|c|c|c|c|c|c|c|}
\hline Location & $\begin{array}{l}\text { Average } \\
\text { Depth } \\
\text { (in:) }\end{array}$ & $\begin{array}{l}\text { Area } \\
\left(\mathrm{ft}^{2}\right)\end{array}$ & $\begin{array}{c}\text { Yolume } \\
\left(\mathrm{ft}^{3}\right)\end{array}$ & $\begin{array}{c}\text { Positive } \\
\text { Uncertainty }\end{array}$ & $\begin{array}{c}\text { Negative } \\
\text { Uncertainty }\end{array}$ & $\begin{array}{c}\text { Minimum } \\
\text { Volume } \\
\left(\mathrm{ft}^{3}\right)\end{array}$ & $\begin{array}{c}\text { Maximum } \\
\text { Volume } \\
\left(f t^{3}\right)\end{array}$ & $\mathrm{N}^{\mathrm{P}}$ \\
\hline Tech View-North Chan & 0.97 & 49.35 & 3.99 & $50 \%$ & $\therefore 50 \%$ & 1.99 & 5.98 & $\ldots \ldots$ \\
\hline Tech View-South Chan & 0.21 & 49.35 & 0.86 & $50 \%$ & $50 \%$ & 0.43 & 1.30 & \\
\hline Tech View Pit & 0.88 & 141.50 & 10.38 & $50 \%$ & $50 \%$ & 5.19 & 15.57 & \\
\hline Weasel Pit Channel & 12.00 & 53.79 & 53.79 & $20 \%$ & $20 \%$ & 43.03 & 64.55 & \\
\hline Weasel Pit & 39.00 & 112.30 & 364.98 & $20 \%$ & $20 \%$ & 291.98 & 437.97 & \\
\hline North Loadout Pit & 33.00 & .66 .53 & 182.96 & 208 & $50 \%$ & 91.48 & 219.55 & \\
\hline North Loadout Chan & 20.00 & 23.18 & 38.63 & $20 \%$ & $20 \%$ & 30.91 & 46.36 & $=$ \\
\hline South Loadout Pit & 5.25 & 64.70 & 28.31 & $50 \%$ & $50 \%$ & 14.15 & 42.46 & $\therefore$ \\
\hline South Loadout Chan & 5.25 & 22.95 & 10.04 & $50 \%$ & $50 \%$ & 5.02 & 15.06 & $\div$ \\
\hline Dumny Elevator Pit ' & 6.00 & 97.00 & 48.50 & $50 \%$ & $50 \%$ & 24.25 & 72.75 & 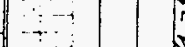 \\
\hline Segregation Pit & 2.00 & 316.50 & 52.75 & $50 \%$ & $50 \%$ & 26.38 & 79.13 & $\therefore-1$ \\
\hline Basin Floor & 1.90 & $4,828.39$ & 764.50 & $20 \%$ & $20 \%$ & 611.60 & 917.39 & $\begin{array}{ll}0 \\
\stackrel{0}{0} \\
\stackrel{0}{D}\end{array}$ \\
\hline Canisters-Empty & 0.22 & 754.70 & 13.84 & $20 \%$ & $20 \%$ & 11.07 & 16.60 & $\cdots$ \\
\hline Canisters-Full, Good & 0.50 & 688.19 & 28.67 & $70 \%$ & $70 \%$ & 8.60 & 46.75 & N. \\
\hline Canisters-Full, Breach & 4.00 & 703.44 & .. 234.48 & -705 & $70 \%$ & 70.34 & 398.62 & 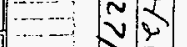 \\
\hline TOTALS ( $\left.\mathrm{ft}^{\mathrm{j}}\right)$ & & & 1.836 .67 & & & $1,236.42$ & $2,382.03$ & $0^{2}$ \\
\hline TOTALS $\left(\mathrm{m}^{3}\right)$ & & & 52.01 & & & 35.01 & .67 .45 & $M$ \\
\hline
\end{tabular}


(9) Checker

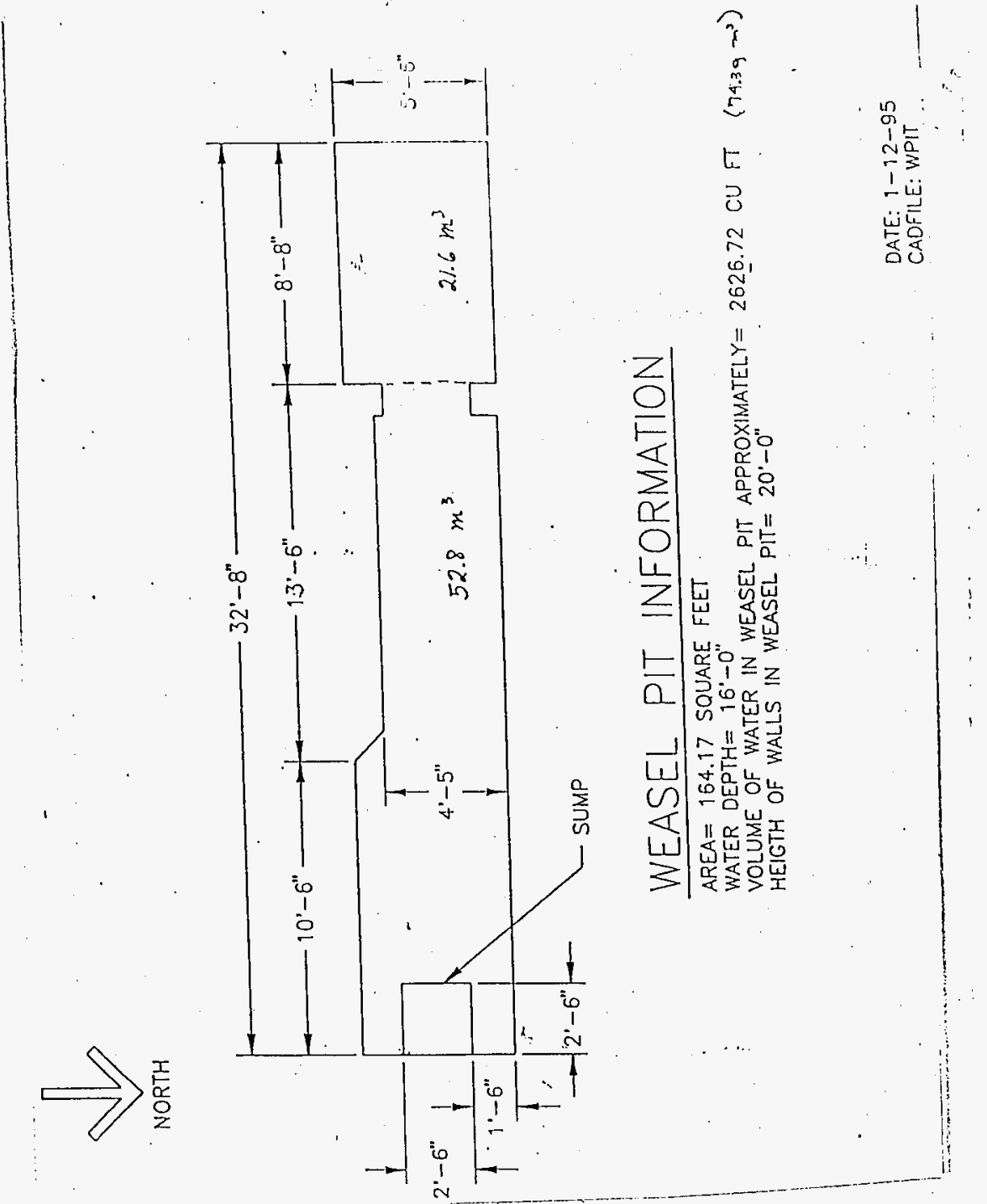


WHC-SD-SNF-OB-012, Rev. 0

ATTACHMENT 2

KE BASIN SLUDGE MANAGEMENT, NOMINAL JUST IN TIME CASE

D.R. Precechtel 


\section{DESIGN CALCULATION}

(1) Drawing

(2) Dor. No.

(3) Page _ 1 of _ 9

(4) Building

(5) Rev.

(6) $J 0 b \mathrm{No}$

(7) Subject

KE Basin Sludge Management

(8) Originator D. R. Precechtel

(9) Checker L. M. Mchethy

QR.fecolte rnumeterts

\section{KE Basin sludge Management}

Calculations of sludge volume management for KE Basin.

1. Sludge volumes as shown in Table 2.1 , page 2.10 , of WHC-SD-SNF-TI-015, Rev. 0. Segregation pit sludge has already been pumped to yeasel pit (see page 8).

2. Weasel pit used for interim storage of all-sludge. Two cases are assumed:

a. siudge is stored only in the weasel pit; with a volume of $52.8 \mathrm{~m}^{3}$ (16 feet deep).

b. Sludge is stored in the weasel pit and the weasel pit channel with a volume of $74.4 \mathrm{~m}^{3}$ (16-1eet deep)

(see page 9).

3. Assume the allowable sludge depth is half the water depth (16 feet nominal, 17 feet after water level increased for dose reduction).

\section{Sludge storage volumes, $\mathrm{m}^{3}$}

Depth

$$
\begin{aligned}
& 8.0^{\prime} \\
& 8.5^{\prime}
\end{aligned}
$$

Weasel pit

26.4

28.05
Weasel pit and channel

37.2

39.53 


\section{Sludge Remova? Sequence}

page $2 / 9$

Just In Time Option, Nominal Sludge Volumes

\begin{tabular}{|c|c|c|c|c|c|}
\hline & Date & $\begin{array}{l}\text { Add } \\
\text { Volume }\end{array}$ & $\begin{array}{l}\text { ded } \\
\text { le }(\mathrm{ft} 3)\end{array}$ & $\begin{array}{l}\text { Added } \\
\text { Volume (m3) }\end{array}$ & $\begin{array}{l}\text { Total } \\
\text { Volume }(\mathrm{m} 3)\end{array}$ \\
\hline 1. & $1 / 96$ & $\begin{array}{l}\text { Weasel Pit } \\
\text { (\& Seg Pit) }\end{array}$ & 417.73 & 11.83 & 11.83 \\
\hline 2. & $\begin{array}{l}2 / 96- \\
3 / 96\end{array}$ & $\begin{array}{l}\text { South load } \\
\text { out pit \& } \\
\text { channel }\end{array}$ & 38.35 & 1.09 & 12.91 \\
\hline 3. & $2 / 96$ & $\begin{array}{l}\text { Debris removal } \\
\text { floor sludge } \\
\text { (canister cleaning } \\
- \text { Bay } 2>1\end{array}$ & 30.00 & 0.85 & 13.76 \\
\hline 4. & $\begin{array}{l}10 / 96- \\
12 / 96\end{array}$ & $\begin{array}{l}\text {-Dummy Elevator } \\
\text { Pit }\end{array}$ & 48.50 & 1.37 & 15.13 \\
\hline 5. & $\begin{array}{l}1 / 97- \\
6 / 97\end{array}$ & $\begin{array}{l}\text { Fuel repackage } \\
\text { cleanup of floor } \\
\text { sludge - Bay } 1>2\end{array}$ & 127.42 & 3.61 & 18.74 \\
\hline 6. & $\begin{array}{l}1 / 97- \\
8 / 97\end{array}$ & $\begin{array}{l}\text { MCO load out } \\
\text { cleanup of floor } \\
\text { sludge - Bay } 1>3\end{array}$ & 63.71 & 1.80 & 20.55 \\
\hline 7. & $\begin{array}{l}4 / 98- \\
10 / 98\end{array}$ & $\begin{array}{l}\text { Fuel canister } \\
\text { sludge removal } \\
\text { - Bay } 1>4\end{array}$ & 92.33 & 2.614 & 23.16 \\
\hline 8. & $\begin{array}{l}10 / 98 \\
5 / 99\end{array}$ & $\begin{array}{l}\text {-Fuel canister } \\
\text { sludge removal } \\
- \text { Bay } 2>4\end{array}$ & 92.33 & 2.614 & 25.77 \\
\hline 9. & $\begin{array}{l}5 / 99- \\
1 / 00\end{array}$ & $\begin{array}{l}\text { Fuel canister } \\
\text { sludge removal } \\
- \text { Bay } 3>4\end{array}$ & 92.33 & 2.614 & 28.39 \\
\hline 10. & $\begin{array}{l}3 / 98- \\
9 / 98\end{array}$ & $\begin{array}{l}60 \% \text { Floor sludge } \\
\text { removal - Bay } 1\end{array}$ & 38.21 & 1.082 & 29.47 \\
\hline 11. & $\begin{array}{l}9 / 98- \\
4 / 99\end{array}$ & $\begin{array}{l}60 \% \text { Floor siudge } \\
\text { Removal - Bay } 2\end{array}$ & 134.90 & 3.820 & 33.29 \\
\hline 12. & $\begin{array}{l}4 / 99- \\
12 / 99\end{array}$ & $\begin{array}{l}60 \% \text { Floor sludge } \\
\text { Removal - Bay } 3\end{array}$ & 152.91 & 4.330 & 37.62 \\
\hline 13. & $\begin{array}{l}12 / 99 \\
11 / 00\end{array}$ & $\begin{array}{l}\text {-Tech View Pit } \\
\text { Weasel Pit Chan. } \\
\text { North Load Out }\end{array}$ & $\begin{array}{l}15.23 \\
53.79 \\
221: 59\end{array}$ & $\begin{array}{l}0.43 \\
1.52 \\
6.27\end{array}$ & 45.84 \\
\hline
\end{tabular}


WHC-SD-SNF-DB-012, Rev. 0

pit \& channel

14. 1/00- Finish floor $5 / 00$ sludge

$>1$ Canister cleaning area - Bay 2 - $15^{\prime} \times 8^{\prime} \times 1 / 4^{\prime}=30 \mathrm{ft} 3$

$>2 \quad 50 \%$ floor sludge removal Bay $1-764.5 / 3 \times .5=127.43 \mathrm{ft} 3$

$>325 \%$ floor sludge removal - Bay $1-764.5 / 3 \times .25=63.71 \mathrm{ft3}$

$>4$ Assumes equal distribution of canister sludge per Bay $276.99 / 3=92.33 \mathrm{ft} 3$ 
WHC-SD-SNF-DB-012, Rev. 0

Date

$3 / 98$

$4 / 98$

$9 / 98$

$10 / 98$

$4 / 99$

$5 / 99$

$12 / 99$

$1 / 00$

$5 / 00$

$11 / 00$
5. Sludge Removal Sequence After 4/98 page 4/9

(Sludge Volumes in $\mathrm{m} 3$ )

Just In Time Option, Nominal Sludge Volumes

\section{Locations}

Fuel Canister

Weasel Sludge

pit

Floor

Sludge

20.55 start Bay 1

start Bay 1

$(2.614)$

20.55

$+.18$

(1.082)

$78^{20.73}+.902$

$+2.178$

$23.81+.902$

$+.436$

finish Bay 1

24.792

$+.546$

finish Bay 1

start Bay 2

start Bay 2

$$
(2.614)+2.241
$$

30.307

$+3.274$

(3.820) 
WHC-SD-SNF-DB-012, Rev. 0

$$
\text { 6. KE Basin STudge Transfer Rate to TWRS }
$$

Just In Time Option, Nominal Sludge Volume

Nominal time to complete a sludge transfer

1. Time to transfer sludge to transport package and take sample

2.5 days

2. Time to complete sample analysis

5 days

3. Time to offload at TWRS and return

2.5 days

Total 10 days

Assume a $6 \mathrm{~m}^{3}$ transport package

Assume sludge volume shipped is $52.01 \mathrm{~m} 3$

Assume 20 working days per month

Time Required for Shipping Sludge

Time per Shipment in days

Shipping Duration, months

$\begin{array}{llll}\% \text { Sludge No. of shipments } & 10 & 12\end{array}$

10

87

2.30

2.76

20

43.5

4.60

5.52

30

29

6.90

8.28

Nominal Shipping Rate: m3/month

5.20

4.33

Conclude that by averaging $20 \%$ sludge in each shipment, at least two transport packages must be running at all times. Availability of crews and vehicles suggests procurement of four transport packages to meet the goal of sludge removal in ten months. 
WHC-SD-SNF-DB-012, Rev. 0

7. Sludge Cleanup/Removal Sequences

Just In Time Option, Nominal Sludge Volumes

$\begin{array}{lcc}\text { Date } & \begin{array}{c}\text { Cumulative } \\ \text { Sludge, } \mathrm{m3}\end{array} & \begin{array}{c}\text { Net Weasel Pit } \\ \text { Volume, } 33\end{array} \\ 01 / 96 & 11.83 & 11.83 \\ 12 / 97 & 20.55 & 20.55 \\ 04 / 98 & 20.73 & 20.73 \\ 9 / 98 & 23.81 & 23.81 \\ 10 / 98 & 24.79 & 24.79 \\ 04 / 99 & 30.31 & 30.31 \\ 05 / 99 & 31.22 & 31.22 \\ 12 / 99 & 37.30 & 37.30 \\ 01 / 00 & 37.62 & 37.62 \\ 05 / 00 & 47.07 & 29.73 \\ 11 / 00 & 52.01 & 8.668 \\ 01 / 01 & 52.01 & 0.00\end{array}$

Assumes 12 months to remove sludge Assumes average sludge removal rate of $4.334 \mathrm{~m} 3 /$ month 


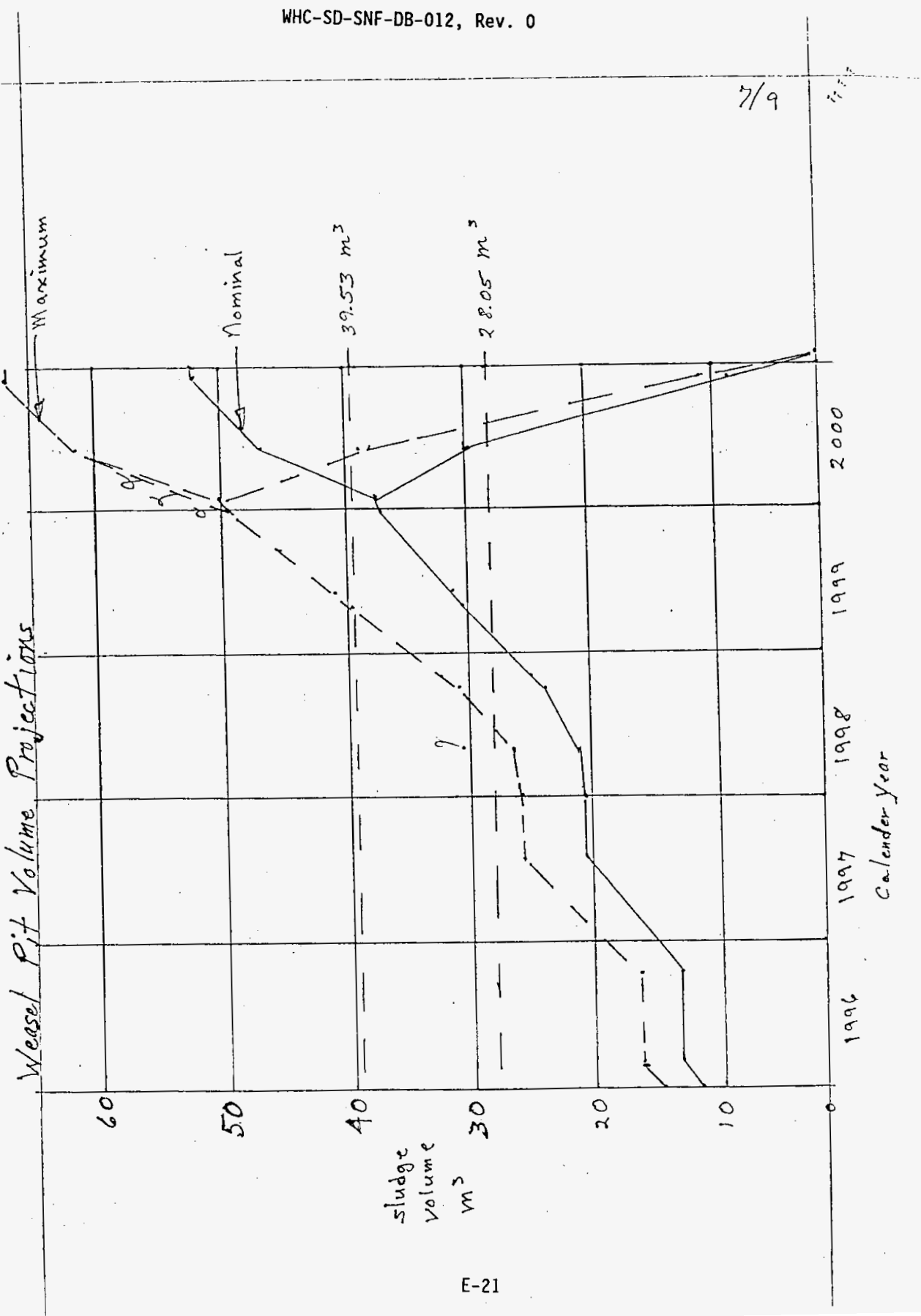




\section{DESIGN CALCULATION}

(i) Drawing

(4) Building

(2) Doc. No.

(7) Subject

(5) Rev.

(3) Page 8 of 9

(8) Originator

$K E$

\section{(5) Rev.}

(9) Checker

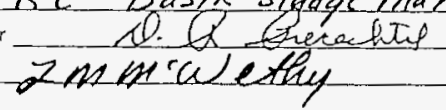

(6) Job No.

(10)

\begin{tabular}{|c|c|c|c|c|c|c|c|c|c|c|c|c|c|c|c|c|c|c|}
\hline & 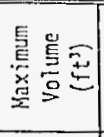 & $\begin{array}{l}\infty \\
\sigma \\
\text { ri }\end{array}$ & $\begin{array}{l}8 \\
2 \\
-1\end{array}$ & $\begin{array}{l}5 \\
5 \\
9 \\
-1\end{array}$ & $\begin{array}{l}3 \\
8 \\
8\end{array}$ & के & $\begin{array}{l}\text { 出 } \\
0 \\
0 \\
2\end{array}$ & $\begin{array}{l}0 \\
? \\
0 \\
0\end{array}$ & 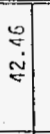 & $\begin{array}{l}0 \\
0 \\
19\end{array}$ & $\begin{array}{l}n \\
\stackrel{n}{N}\end{array}$ & $\begin{array}{l}? \\
? \\
9 \\
r\end{array}$ & $\begin{array}{l}9 \\
7 \\
\Xi \\
\sigma\end{array}$ & : & $\begin{array}{l}5 \\
0 \\
5\end{array}$ & 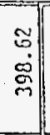 & $\begin{array}{l}\tilde{a} \\
\tilde{m} \\
\tilde{m} \\
\end{array}$ & $\stackrel{5}{6}$ \\
\hline 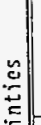 & 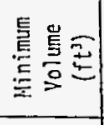 & $\begin{array}{l}9 \\
0 \\
-i\end{array}$ & $\stackrel{2}{0}$ & $\stackrel{0}{\because}$ & $\begin{array}{l}m \\
\dot{m} \\
\dot{p}\end{array}$ & 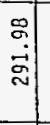 & \begin{tabular}{l}
$\infty$ \\
\hdashline \\
-5
\end{tabular} & $\begin{array}{l}\overrightarrow{0} \\
0 \\
0\end{array}$ & $\begin{array}{l}2 \\
\vdots \\
\vdots\end{array}$ & $\begin{array}{c}\widetilde{0} \\
\text { जi }\end{array}$ & $\begin{array}{l}\stackrel{L}{\sim} \\
\stackrel{s}{\sim}\end{array}$ & $\begin{array}{l}\infty \\
m \\
\dot{N}\end{array}$ & $\begin{array}{c}8 \\
\vdots \\
\end{array}$ & $\begin{array}{l}0 \\
=\end{array}$ & $\begin{array}{l}8 \\
0 \\
\infty\end{array}$ & $\begin{array}{l}\vec{m} \\
\dot{R}\end{array}$ & 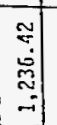 & $\begin{array}{l}-1 \\
0 \\
m\end{array}$ \\
\hline 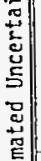 & 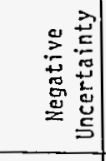 & 恕 & 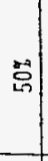 & 恕 & 总 & $\stackrel{\text { 今a }}{\mathrm{s}}$ & 영 & 옹 & 员 & 点 & $\stackrel{8}{0}$ & 吕 & : & 足 & 员 & 롱 & & \\
\hline 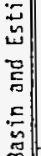 & 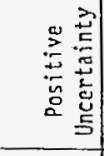 & 염 & 总 & $\stackrel{+a}{0}$ & 요 & : & 오 & $\stackrel{\rightarrow}{\circ}$ & $\begin{array}{l}\text { : } \\
\text { 옹 }\end{array}$ & 品 & 영 & 哭 & : & 总 & $\stackrel{g}{\rho}$ & 몸 & & \\
\hline 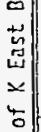 & $\stackrel{\stackrel{D}{5}}{\frac{5}{5}}$ & $\begin{array}{l}\text { g. } \\
\text { mi }\end{array}$ & $\begin{array}{l}\mathscr{0} \\
\vdots \\
0\end{array}$ & \begin{tabular}{l}
\multicolumn{2}{|c}{} \\
$\dot{\Xi}$
\end{tabular} & $\begin{array}{l}q \\
2 \\
\text { rin }\end{array}$ & $\begin{array}{l}0 \\
0 \\
\vdots \\
0 \\
m\end{array}$ & 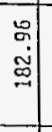 & $\begin{array}{l}9 \\
\dot{m} \\
\dot{m}\end{array}$ & $\begin{array}{l}\overrightarrow{3} \\
\vec{n}\end{array}$ & $\begin{array}{l}5 \\
0 \\
0\end{array}$ & $\begin{array}{l}0 \\
+1 \\
0\end{array}$ & $\begin{array}{l}n \\
\stackrel{n}{n} \\
\end{array}$ & $\begin{array}{l}0 \\
? \\
5 \\
5\end{array}$ & $\begin{array}{l}\bar{\omega} \\
\dot{m}\end{array}$ & مే & 品 & $\begin{array}{l}0 \\
0 \\
0 \\
0 \\
-1 \\
-1\end{array}$ & $\begin{array}{l}\vec{\delta} \\
\dot{\sigma}\end{array}$ \\
\hline 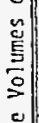 & 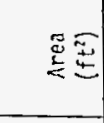 & m & $\begin{array}{l}\text { ?n } \\
? \\
\stackrel{2}{*}\end{array}$ & 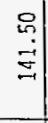 & 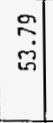 & $\begin{array}{l}\text { 号 } \\
\stackrel{2}{\Xi}\end{array}$ & 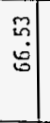 & $\begin{array}{l}\infty \\
\stackrel{-}{2} \\
\stackrel{N}{2}\end{array}$ & $\begin{array}{l}8 \\
5 \\
5\end{array}$ & 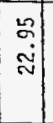 & $\begin{array}{l}8 \\
\text { के }\end{array}$ & $\begin{array}{l}0 \\
0 \\
0 \\
m\end{array}$ & 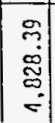 & $\begin{array}{l}0 \\
\stackrel{5}{N}\end{array}$ & $\begin{array}{l}9 \\
0 \\
0 \\
0\end{array}$ & $\begin{array}{r}\Sigma \\
\dot{8}\end{array}$ & & \\
\hline $\begin{array}{l}\frac{g}{\mathrm{~g}} \\
\stackrel{5}{n} \\
-\dot{m}\end{array}$ & 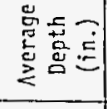 & $\hat{0}$ & \begin{tabular}{l}
- \\
\hdashline \\
0
\end{tabular} & $\begin{array}{l}\mathscr{g} \\
\dot{0}\end{array}$ & $\begin{array}{l}8 \\
\stackrel{1}{\simeq}\end{array}$ & $\begin{array}{l}\text { D. } \\
\text { g. }\end{array}$ & $\begin{array}{l}8 \\
m \\
m\end{array}$ & $\begin{array}{l}8 \\
0 \\
0 \\
0\end{array}$ & $\begin{array}{l}\stackrel{2}{\circlearrowleft} \\
\dot{\omega n}\end{array}$ & $\stackrel{2}{\stackrel{2}{*}}$ & $\begin{array}{l}8 \\
0\end{array}$ & $\begin{array}{l}8 \\
\vdots \\
\vdots\end{array}$ & \begin{tabular}{l}
8 \\
\hdashline \\
-1
\end{tabular} & 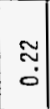 & 요 & 8 & & \\
\hline$\frac{0}{5}$ & 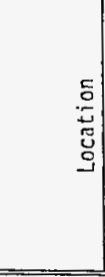 & 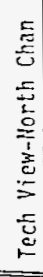 & 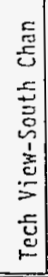 & 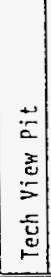 & 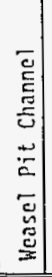 & 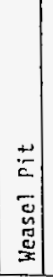 & 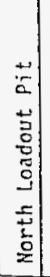 & 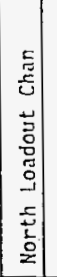 & 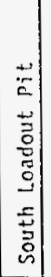 & 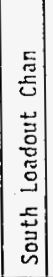 & 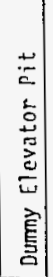 & 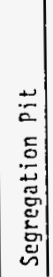 & 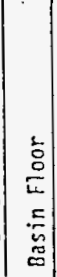 & 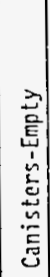 & $\begin{array}{c}\square \\
8 \\
0 \\
- \\
5 \\
5 \\
1 \\
5 \\
5 \\
5 \\
5 \\
5 \\
5 \\
5\end{array}$ & 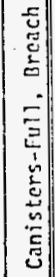 & 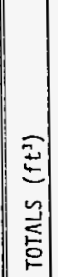 & $\stackrel{2}{2}$ \\
\hline
\end{tabular}




\section{DESIGN CALCULATION}

(1) Drawing

(2) Doc. No

(3) Page 9 of 9

(4) Building

(5) Rev

(6) $\operatorname{Job} \mathrm{No}$

(7) Subject

$K \epsilon$

(8) Originator

(9) Checker

Lmmilethy

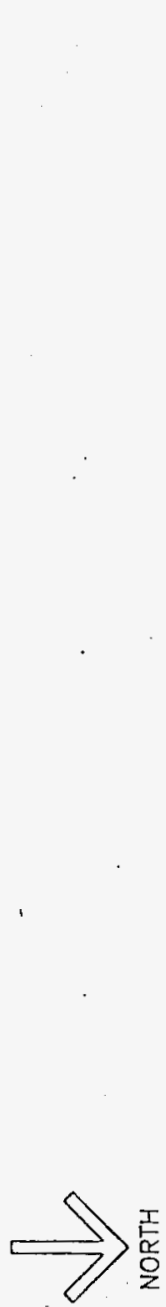

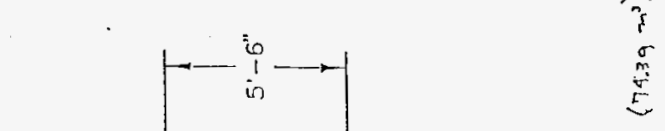

t.

3

N

is

io

穴

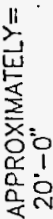

동

$\longrightarrow$ 工

Z訬 嵌

is $<0$

$w: \xi \frac{w}{3}$

ㄴ $\quad \begin{aligned} & w \\ & \alpha\end{aligned}$

口.

可

U) ڤ岁岁

<

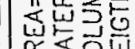

$\sum$ 定京

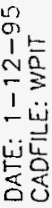


WHC-SD-SNF-DB-0 12 , Rev.

\author{
ATTACHMENT 3 \\ KE BASIN SLUDGE MANAGEMENT, MAXIMUM JUST IN TIME CASE \\ D.R. Precechtel
}




\section{DESIGN CALCULATION}

(1) Drawing

(2) Doc, No (3) Page 1 of 9

(4) Building

(5) Rev

Maxiaum (6) Job No.

(7) Subject KE Basin Sludge Management

nt

(8) Originator D. R. Precechtel

(9) Checker L. M. Mclethy Date $2 / 27 / 96$

\section{KE Basin Sludge Management}

Calculations of sludge volume management for $\mathrm{KE}$ Basin.

1. Sludge volumes as shown in Table 2.1, page 2.10, of WHC-SD-SNF-TI-015, Rev. 0: Segregation pit sludge has already been pumped to weasel pit (see page 8) ..........

2. Weasel pit used for interim storage of-all sludge. ... Two cases are assumed:

a. Sluage is stored only in the weasel-pit; with a volume of $52.8 \mathrm{~m}^{3}$ (16 feet deep).

b. Sludge is stored in the weasel pit and the weasel pit channel with a volume of $74.4 \mathrm{~m}^{3}$ (16-feet deep) (see page 9).

3. Assume the allowable sludge depth is half ...the water..depth (16 feet nominal, 17 feet after water level increased for dose reduction).

\section{Sludge storage volumes, $\mathrm{m}^{3}$}

Depth

$$
\begin{aligned}
& 8.0^{\prime} \\
& 8.5^{\prime}
\end{aligned}
$$

Weasel pit

26.4

28.05
Weasel pit and channel

37.2

39.53 


\section{Sludge Removal Sequence}

page 2/9

Just In Time Option, Maximum Sludge Volumes

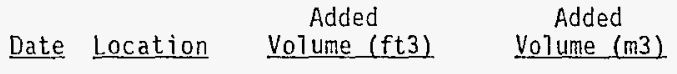

14.64

Total
1. 1/96 Weasel Pit
(\& Seg Pit)
517.10
2. $2 / 96-$ South Toad
$3 / 96$ out pit \&
channel
3. $2 / 96$ Debris removal 36.00
floor sludge
(canister cleaning)
- Bay $2>1$

4. 10/96-Dummy Elevator $\quad 72.75$

2.06

19.35

12/96 Pit

5. 1/97- Fuel repackage
$6 / 97$ cleanup of fioor sludge - Bay $1>2$

6. 1/97- MCO load out
$8 / 97$ Cleanup of floor

76.45

2.17

25.85

sludge - Bay $1>3$

7. 4/98-Fuel canister $\quad 154.66$

4.38

30.23

$10 / 98$ sludge removal

- Bay $1>4$

8. 10/98-Fue] canister $\quad 154.66$

$5 / 99$ sludge removal

- Bay $2>4$

9. 5/99- Fuel canister

$1 / 00$ sludge remova?

- Bay $3>4$.

10. $3 / 98-60 \%$ Floor sludge 45.87

9/98 removal - Bay I

154.66

4.38

38.99

$4.38 \quad \cdot 34.61$

11. 9/98- $60 \%$ Floor sludge 161.88

4/99 Removal - Bay 2

40.28

4.58

44.87

12. $4 / 99-60 \%$ Floor sludge 183.48 12/99 Removal - Bay 3

$5.20 \quad 50.06$

13. 12/99-Tech View Pit 22.85

$11 / 00$. Wease? Pit Chan. 64.55

North Load Out 265.91 
WHC-SD-SNF-DB-012, Rev. 0

$3 / 9$

pit \& channel

14. 1/00-Finish floor

260.81

7.39

67.45

5/00 sludge

$>1$ Canister cleaning area - Bay $2-15^{\prime} \times 8^{\prime} \times 0.3^{\prime}=36 \mathrm{ft} 3$

$>250 \%$ floor sludge removal - Bay $1-917.39 / 3 \times .5=152.90 \mathrm{ft} 3$

$>325 \%$ floor sludge removal - Bay $1-917.39 / 3 \times .25=76.45 \mathrm{ft3}$

$>4$ Assumes equal distribution of canister siudge per Bay $463.97 / 3=154.66 \mathrm{ft3}$ 


\section{Sludge Removal Sequence After $4 / 98$ page $4 / 9$ (Sludge Volumes in $\mathrm{m} 3$ )}

Just In Time Option, Maximum Sludge Volumes

\section{Locations}

Date

$3 / 98$

$4 / 98$

$9 / 98$

$10 / 98$

4/99

$5 / 99$

$12 / 99$

$1 / 00$

$5 / 00$

$11 / 00$

\section{Fuel Canister} sludge

\section{Weasel}

Pit

25.845

26.061

start Bay $]$

(4.380)

$+3.650$

$30.793^{+1}$

$$
+.730+.655
$$

32.178

finish Bay 1

$$
\text { start Bay } 2
$$

Floor

Sludge

Pit

sludge

start Bay 1

$$
(4.380)+3.754+3.929
$$




$$
\text { 6. KE Basin Sludqe Transfer Rate to TWRS }
$$

Just In Time Option, Maximum Sludge Volume

Nominal time to complete a sludge transfer

1. Time to transfer sludge to transport package and take sample 2.5 days

2. Time to complete sample analysis 5 days

3. Time to offload at TWRS and return 2.5 days

Total 10 days

Assume a $6 \mathrm{~m} 3$ transport package

Assume sludge volume shipped is $67.45 \mathrm{~m} 3$

Assume 20 working days per month

Time Required for Shipping Sludge

Time per Shipment in days

Shipping Duration, months

\% Sludge No. of shipments $\quad 10 \quad 12$

$\begin{array}{llll}10 & 112 & 1.78 & 2.13\end{array}$

$\begin{array}{llll}20 & 56 & 3.56 & 4.23\end{array}$

$\begin{array}{llll}30 & 37.5 & 5.34 & 6.40\end{array}$

Nominat Shipping Rate: $\mathrm{m} 3 /$ month $\quad 6.75 \quad 5.62$

Conclude that by averaging $20 \%$ sludge in each shipment, about three transport packages must be running at all times. Availability of crews and vehicles suggests procurement of four transport packages to meet the goal of sludge removal in ten months. 
WHC-SD-SNF-DB-012, Rev. 0

$$
\text { 7. Sludge Cleanuo/Remava? Sequences }
$$

Just In Time Option, Maximum Sludge Volumes

$\begin{array}{lcc}\text { Date } & \begin{array}{c}\text { Cumulative } \\ \text { Sludge, m3 }\end{array} & \begin{array}{c}\text { Net Wease? Pit } \\ \text { Volume, m3 }\end{array} \\ 01 / 96 & 14.64 & 14.64 \\ 12 / 97 & 25.85 & 25.85 \\ 04 / 98 & 26.06 & 26.06 \\ 9 / 98 & 30.79 & 30.79 \\ 10 / 98 & 32.18 & 32.18 \\ 04 / 99 & 39.86 & 39.86 \\ 05 / 99 & 41.14 & 41.14 \\ 12 / 99 & 49.52 & 49.52 \\ 01 / 00 & 50.06 & 50.06 \\ 05 / 00 & 61.45 & 38.97 \\ 11 / 00 & 67.45 & 11.25 \\ 01 / 01 & 67.45 & 0.00\end{array}$

Assumes 12 months to remove sludge

Assumes average sludge removal rate of $5.621 \mathrm{~m} 3 / \mathrm{month}$ 


\section{DESIGN CALCULATION}

(1) Drawing

(2) DoC NO

(3) Page 8 of $9 \quad \therefore$

(4) Building

(5) Rev

(6) Job No.

(7) Subject

$K E$

(8) Originator

(9) Checker

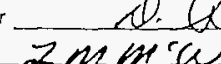

Slydar management

(10)

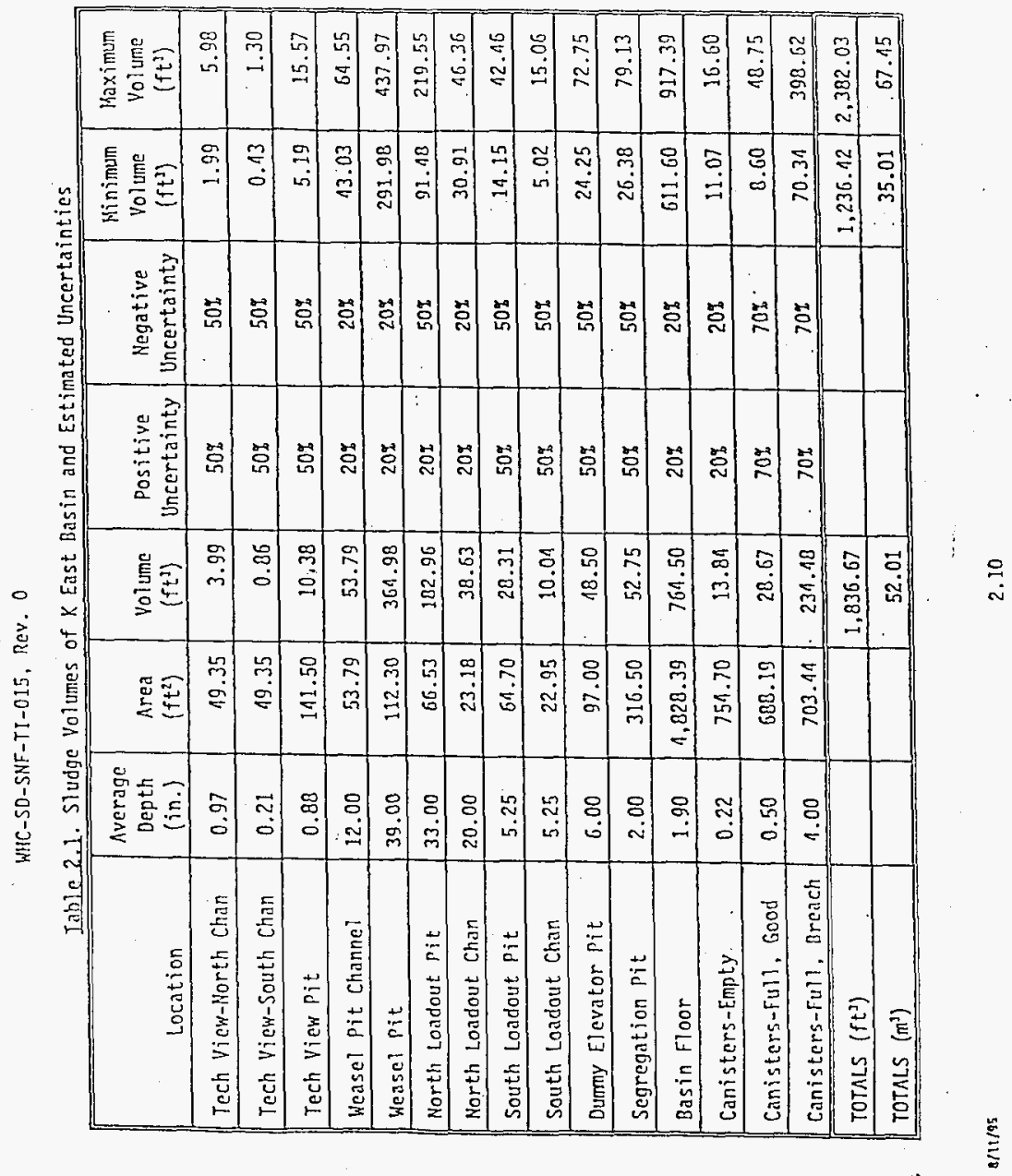




\section{DESIGN CALCULATION}

(1) Drawing

(4) Building

(2) Dor. No.

(3) Page 9 of 9

(7) Subject

(5) Reev

(6) Job No.

(8) Originator

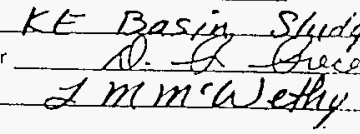

Managument

(9) Checker

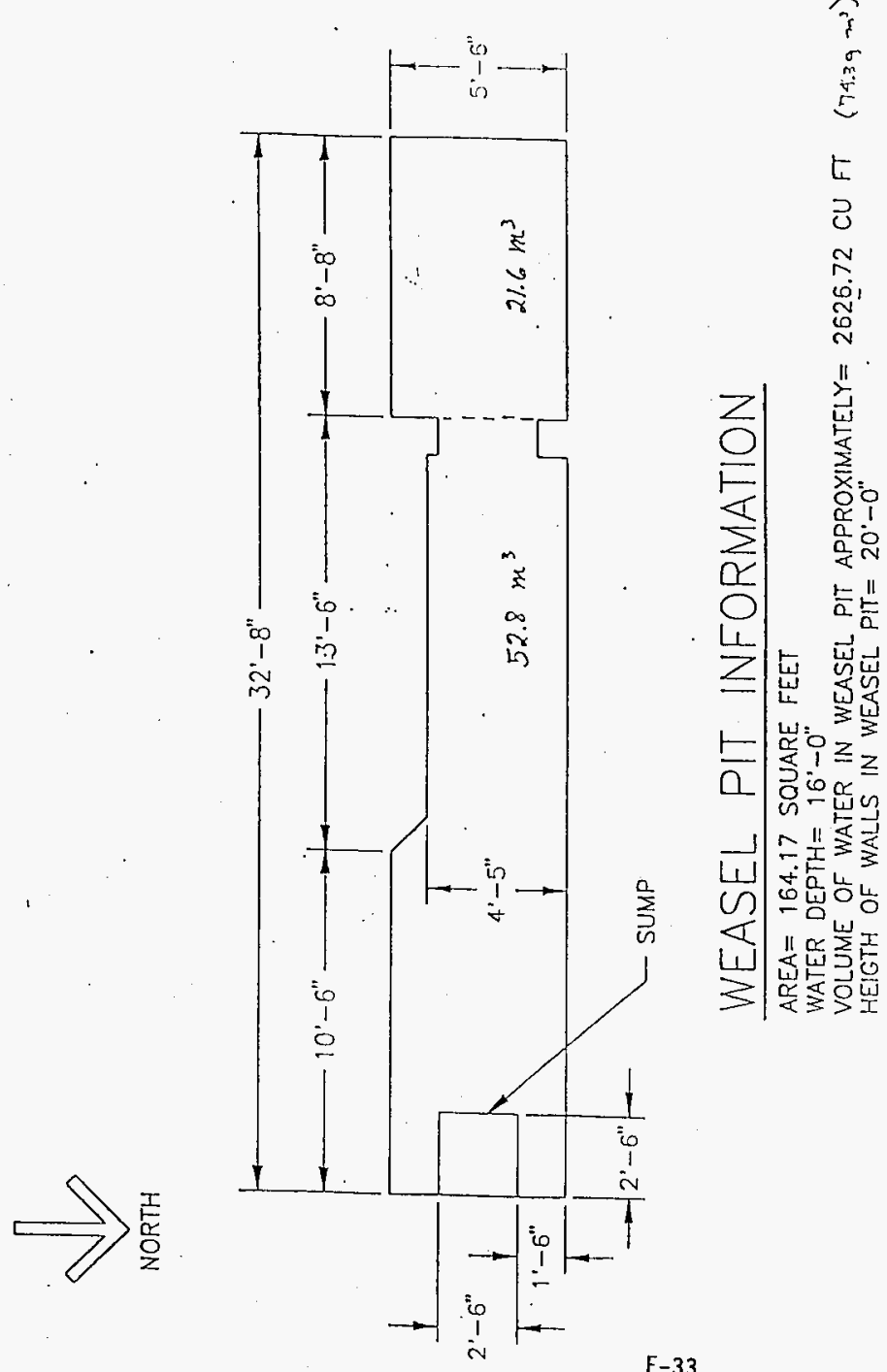

Date

$2 / 26 / 46$

Date $2 / 27 / 96$

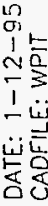




\begin{tabular}{|c|c|c|c|c|c|}
\hline \multicolumn{6}{|c|}{ DISTRIBUTION SHEET } \\
\hline \multirow{2}{*}{$\begin{array}{l}\text { To } \\
\text { Engineering Support }\end{array}$} & \multirow{2}{*}{\multicolumn{2}{|c|}{$\begin{array}{l}\text { From } \\
\text { Engineering Support }\end{array}$}} & & \multicolumn{2}{|c|}{ Page 1 of 1} \\
\hline & & & & \multicolumn{2}{|c|}{ Date $9 / 12 / 96$} \\
\hline \multicolumn{4}{|l|}{ Project Title/Work Order } & \multicolumn{2}{|c|}{ EDT No. 616144} \\
\hline Sludge Removal Project & rements & & & \multicolumn{2}{|c|}{ ECN No. $N / A$} \\
\hline Name & MSIN & $\begin{array}{c}\text { Text } \\
\text { With All } \\
\text { Attach. }\end{array}$ & Text Only & $\begin{array}{l}\text { Attach./ } \\
\text { Appendix } \\
\text { Only }\end{array}$ & $\begin{array}{l}\text { EDT/ECN } \\
\text { Only }\end{array}$ \\
\hline $\begin{array}{l}\text { C. J. Alderman } \\
\text { K. H. Bergsman } \\
\text { S. A. Brisbin } \\
\text { J. R. Frederickson } \\
\text { E. W. Gerber } \\
\text { M. A. Jensen } \\
\text { F. W. Moore } \\
\text { F. J. Muller } \\
\text { M. J. Packer } \\
\text { T. R. Pauly } \\
\text { K. L. Pearce } \\
\text { C. C. Pitkoff } \\
\text { D. R. Precechtel } \\
\text { R. A. Schwarz } \\
\text { E. D. Takasumi } \\
\text { M. J. Wiemers } \\
\text { SNF Project File } \\
\text { Central Files (2) }\end{array}$ & $\begin{array}{l}\text { R3-48 } \\
\text { R3-48 } \\
\text { R3-48 } \\
\text { R3-86 } \\
\text { R3-86 } \\
\text { X3-79 } \\
\text { X3-85 } \\
\text { X3-85 } \\
\text { R3-48 } \\
\text { X3-85 } \\
\text { R3-48 } \\
\text { X3-85 } \\
\text { R3-48 } \\
\text { H0-35 } \\
\text { X3-85 } \\
\text { X3-85 } \\
\text { R3-11 } \\
\text { A3-88 } \\
\end{array}$ & 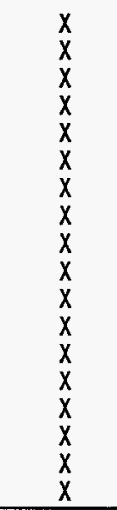 & & & \\
\hline
\end{tabular}

